\title{
DESENVOLVIMENTO FLORAL DE Caesalpinia echinata LAM, Caesalpinia peltophoroides BENTH E Caesalpinia férrea VAR. leyotachia BENTH. (FABACEAEI CAESALPINIOIDEAE)
}

\author{
HERIKA APARECIDA BEQUIS DE ARAUJo ZAIA
}

\begin{abstract}
Dissertação apresentada à Escola Superior de Agricultura "Luiz de Queiroz", Universidade de São Paulo, para obtenção do título de Mestre em Recursos Florestais, com opção em Silvicultura.
\end{abstract}

$P \mid R A C I C A B A$

Estado de São Paulo - Brasil

Abril - 2004 


\title{
DESENVOLVIMENTO FLORAL DE Caesalpinia echinata LAM, Caesalpinia peltophoroides BENTH E Caesalpinia ferrea VAR. leyotachia BENTH. (FABACEAEI CAESALPINIOIDEAE)
}

\author{
HERIKA APARECIDA BEQUIS de ARAUjo ZAIA \\ Bióloga
}

Orientador: Dr. MARCELO CARNIER DORNELAS

Dissertação apresentada à Escola Superior de Agricultura "Luiz de Queiroz", Universidade de São Paulo, para obtenção do título de Mestre em Recursos Florestais, com opção em Silvicultura.

P I R A C I C A B A

Estado de São Paulo - Brasil

Abril - 2004 


\section{Dados Internacionais de Catalogação na Publicação (CIP)}

DIVISÃO DE BIBLIOTECA E DOCUMENTAÇÃO - ESALQ/USP

\section{Zaia, Herika Aparecida Bequis de Araújo}

Desenvolvimento floral de Caesalpinia echinata Lam, Caesalpinia peltophoroides Benth e Caesalpinia ferrea Benth var. leyotachia

(Fabaceae/Caesalpinioideae) / Herika Aparecida Bequis de Araújo Zaia. - -

Piracicaba, 2004

53 p. : il.

Dissertação (mestrado) - Escola Superior de Agricultura Luiz de Queiroz, 2004. Bibliografia.

1. Fabaceae 2. Filogenia 3. Microscopia eletrônica de varredura 4. Morfogênese vegetal 5. Ontogenia 6. Pau-Brasil 7. Pau-Ferro 8. Reprodução vegetal 9. Sibipiruna I. Título

CDD 634.973323

\section{"Permitida a cópia total ou parcial deste documento, desde que citada a fonte - $\mathrm{O}$ autor"}


"O valor das coisas não está no tempo em que elas duram, mas na intensidade com que acontecem. Por isso existem momentos inesquecíveis, coisas inexplicáveis e pessoas incomparáveis".

Meu marido, Alexandre Zaia, pelo amor e por ter me ajudado a enfrentar as dificuldades com serenidade e otimismo.

\section{DEDICO}

À minha mãe Fátima e minha irmã Ana Claudia, pelo apoio, amizade, palavras de incentivo e minha educação.

OFEREÇO 


\section{AGRADECIMENTOS}

À Deus, pela constante presença em minha vida.

Ao Prof. Dr. Marcelo Carnier Dornelas (CENA/USP) pela orientação, confiança, constante disponibilidade e oportunidade de realização do trabalho.

À Profa. Dra. Adriana Pinheiro Martinelli Rodriguez (CENA/USP), pelo constante auxílio e sugestões durante toda realização do trabalho. Pela atenção e amizade. Gostaria de registrar toda minha admiração.

À Escola Superior de Agricultura "Luiz de Queiroz", em especial ao Departamento de Ciências Florestais, pela oportunidade de realização deste curso de Mestrado.

Ao Laboratório de Biotecnologia Vegetal (CENA/USP), onde foram realizados os experimentos.

À FAPESP, pela bolsa de estudo e auxílio financeiro fornecido ao projeto de pesquisa (Processo $\mathrm{N}^{0} 01 / 12812-2$ ).

Aos estagiários e pós-graduandos do Laboratório de Biotecnologia Vegetal (CENA/USP).

Ao Núcleo de Apoio à Pesquisa/ Microscopia Eletrônica na Pesquisa Agropecuária-NAP/ MEPA (ESALQ/USP), pela utilização dos equipamentos e microscópio eletrônico de varredura.

Ao Prof. Dr. Elliot W. Kitajima (NAP/ MEPA - ESALQ/ USP), pelo auxílio na realização das análises de Microscopia Eletrônica de Varredura.

Ao amigo João Geraldo Brancalion, do Laboratório de Instrumentação e Informática (CENA/USP), pela colaboração e serviços de computação gráfica. 
As bibliotecárias Eliana Maria Garcia e Silvia Maria Zinsly pela revisão das referências bibliográficas.

Ao meu "pai" padrasto Flavio, cunhado Wilson e sobrinho João Pedro pelo carinho e atenção.

Aos meus grandes amigos Jannayna Barbosa, Fernanda Mendes da Glória, Sandra C. Arruda, Girlene S. Souza, Nailton S. Almeida, Alice Franco Peres, Flavio Trevisan, Cantidio F. Gouveia, Gustavo A. Pereira, Liliane Sttipp (Lili), Joanne Neves, Daniela Vieira, Welliton Almeida, Márcio L. Tomaz pelo auxílio sempre que necessário, companheirismo, respeito e amizade. Muito obrigada.

Às amigas Raquel L. Buscariol e Maria Graziela Z. Krug (Zizi) pela amizade e apoio e convívio.

À amiga Mayra Faion pela grandiosa ajuda durante a execução deste trabalho. Muito obrigada.

Para todos aqueles que contribuíram direta ou indiretamente para a realização deste trabalho. 


\section{SUMÁRIO}

Página

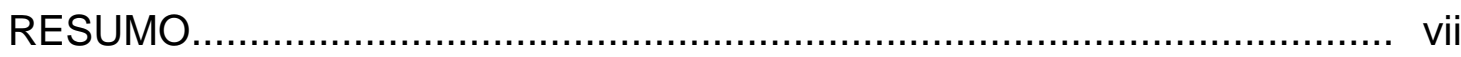

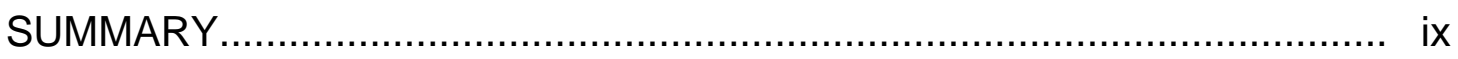

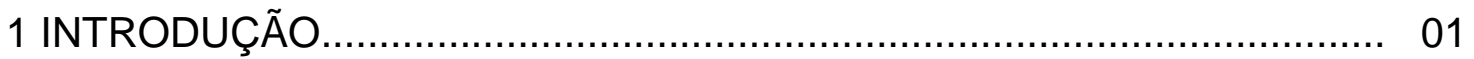

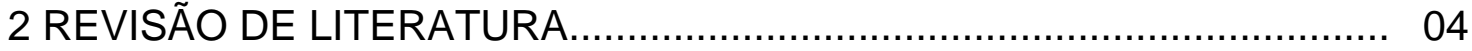

2.1 Relações filogenéticas da família Fabaceae ...................................... 04

2.2 Desenvolvimento floral em Fabaceae/ Caesalpinioideae...................... 08

3 MATERIAL E MÉTODOS................................................................. 13

3.1 Microscopia eletrônica de varredura MEV ........................................ 14

3.2 Microscopia óptica MO............................................................. 14

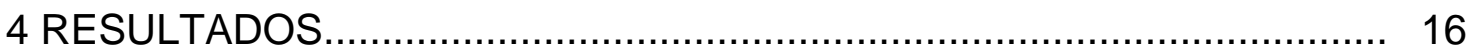

4.1 Estudo morfo-anatômico do desenvolvimento reprodutivo de

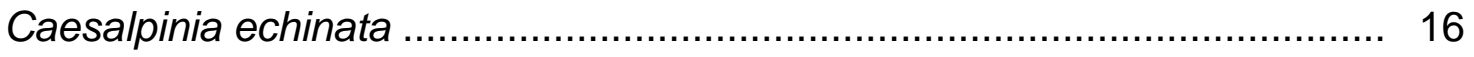

4.2 Estudo morfo-anatômico do desenvolvimento reprodutivo de Caesalpinia peltophoroides............................................................. 27

4.3 Estudo morfo-anatômico do desenvolvimento reprodutivo de Caesalpinia ferrea var. leyotachia.......................................................... 33

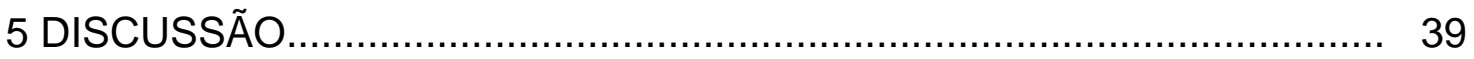

5.1 Comparação do desenvolvimento floral de C. echinata, $C$. peltophoroides e C. ferrea var. leyotachia.............................................. 39

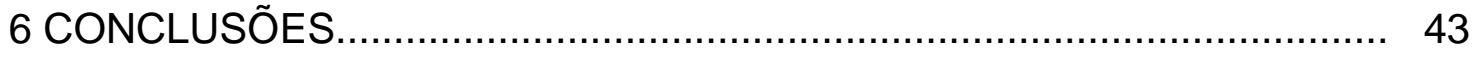

REFERÊNCIAS BIBLIOGRÁFICAS....................................................... 45 


\title{
DESENVOLVIMENTO FLORAL DE Caesalpinia echinata LAM, Caesalpinia peltophoroides BENTH E Caesalpinia ferrea BENTH Var. leyotachia (FABACEAEI CAESALPINIOIDEAE)
}

\author{
Autora: HERIKA APARECIDA BEQUIS DE ARAUJO ZAIA \\ Orientador: Dr. MARCELO CARNIER DORNELAS
}

\section{RESUMO}

O estudo da ontogênese floral é essencial para uma melhor compreensão dos processos evolutivos envolvidos no desenvolvimento dos órgãos reprodutivos dos vegetais. Este trabalho teve por objetivo analisar a ontogênese floral das espécies C. echinata, C. peltophoroides e C. ferrea, da família Fabaceae/ Caesalpinioideae Foram realizados estudos morfo-anatômicos com o emprego de técnicas de microscopia eletrônica de varredura e microscopia óptica. Os resultados obtidos permitiram determinar que a ontogênese floral das três espécies são similares: o meristema da inflorescência é indeterminado e inicia a formação de brácteas acropetalarmente. Cada bráctea protege um único meristema floral. O primórdio da sépala abaxial é o primeiro a ser formado 
pelo meristema floral, seguido dos primórdios das sépalas laterais e adaxiais, de forma unidirecional. Os primórdios das pétalas e dos estames epissépalos e epipétalos são iniciados a seguir. A formação do carpelo inicia-se com a formação de uma protuberância no centro do meristema floral e quando o primórdio do carpelo atinge cerca de $100 \mu \mathrm{m}$ de altura, o mesmo inicia uma invaginação em seu lado adaxial formando uma fenda cuja superfície interna originará a placenta. Nos estágios que precedem a antese, há a diferenciação de células papilares no estigma. Os resultados obtidos neste trabalho de descrição da ontogênese floral em Caesalpinia poderão servir de fundamentação para futuros estudos dos aspectos moleculares do desenvolvimento reprodutivo em leguminosas. 


\title{
FLORAL DEVELOPMENT IN Caesalpinia echinata LAM, Caesalpinia peltophoroides BENTH E Caesalpinia ferrea BENTH Var. leyotachia (FABACEAEI CAESALPINIOIDEAE)
}

\author{
Author: HERIKA APARECIDA BEQUIS DE ARAUJO ZAIA \\ Adiviser: Dr. MARCELO CARNIER DORNELAS
}

\section{SUMMARY}

The study of the floral ontogeny is essential for the understanding the evolutionary processes involved in the development of the floral organs. The aim of this work was to analyse the floral ontogeny the species $C$. echinata, $C$. peltophoroides and C. ferrea, from the family Fabaceae/ Caesalpinioideae. Scanning electron microscopy and light microscopy techniques were used. The observed results indicated that the ontogeny events of the tree species were similar: the inflorescence apical meristem is indeterminate and initiates bracts in an acropetal order. Each bract protects a single floral meristem. The first floral organ formed is the abaxial sepal and it is followed by the lateral and adaxial sepal primordia in a unidirecional order. The whorls of petal and antepetalous and antesepalous stamen primordial are the next to begin. The carpel 
primordium arise as a mound in the center of the floral meristem. When the carpel primordium is about $100 \mu \mathrm{m}$ high, a cleft is formed in its adaxial side, on the site where the placenta will be formed. At anthesis, the stigma differentiates papilate cells. The results obtained with this descriptive work will serve as a foundation for future studies of the molecular aspects of reproductive development of legumes. 


\section{INTRODUÇÃo}

Até recentemente, as leguminosas foram consideradas originárias da África no período Cretáceo, de onde migraram para a América do Sul e conseqüentemente para a América do Norte, deixando gêneros primitivos na África (Polhill \& Raven, 1981).

Apesar de todas as incertezas que ainda cercam a evolução das leguminosas, provavelmente dos três subgrupos que constituem a família Fabaceae, a subfamília Caesalpinioideae é a mais primitiva, porque apresenta maiores semelhanças com as espécies fósseis que deram origem à família e tem posição basal em estudos filogenéticos (Lewis, 1998; Doyle et al., 2000; Bruneau et al., 2001; Tucker, 2003).

Caesalpinia echinata Lam, ou "pau-brasil", Caesalpinia ferrea Benth var. leyotachia, ou "pau-ferro" e Caesalpinia peltophoroides Benth, ou "sibipiruna" são angiospermas, pertencentes à ordem Fabales, que contém aproximadamente 18.860 espécies, distribuídas em 3 famílias: Poligalaceae, Surianaceae e Fabaceae (Judd et al., 1999). Na família Fabaceae, três subfamílias podem ser reconhecidas: Caesalpinioideae, Mimosoideae e Faboideae (Judd et al., 1999; Doyle et al., 2000). A subfamília Caesalpinioideae 
e o gênero Caesalpinia são identificados por certas peculiaridades de sua morfologia floral, como flores geralmente hermafroditas, com simetria radial ou bilateral e inflorescências indeterminadas (Judd et al., 1999; Tucker, 2003). As espécies aqui estudadas, C. echinata, C. peltophoroides e C. ferrea apresentam estas características e são, portanto, representativas do gênero Caesalpinia.

Nas últimas décadas houve uma reavaliação da relação entre ontogenia e filogenia e sua importância para o entendimento do processo evolutivo (Gould, 1977; Alberch et al., 1979; Alberch, 1985). Assim, a relação entre morfologia e a evolução das flores tem sido por muito tempo, um objeto de estudos de sistematas, geneticistas e ecologistas (Hufford \& Diggle, 1997; Tucker, 2003).

O interesse no estudo do desenvolvimento dos órgãos florais aumentou muito nas últimas décadas, devido a uma conjunção de fatores como os avanços em estudos de genética molecular e uma melhor compreensão dos mecanismos moleculares do desenvolvimento. Um dos entraves ao melhoramento genético das espécies arbóreas de interesse econômico é o longo tempo de geração e a falta de conhecimento sobre a biologia reprodutiva, com ênfase no desenvolvimento floral.

Devido a pouca informação disponível na literatura com relação ao desenvolvimento floral e origem dos hábitos reprodutivos no gênero Caesalpinia, é fundamental a realização de estudos básicos que permitam a descrição e o melhor entendimento do processo de desenvolvimento reprodutivo neste grupo importante de espécies arbóreas. 
O presente trabalho visa contribuir para o entendimento do desenvolvimento floral da família Fabaceae, subfamília Caesalpinioideae, com destaque para a espécie $C$. echinata (pau-brasil), de alto interesse histórico, econômico e ecológico.

Foram realizadas análises morfo-anatômicas com o auxílio de microscopia eletrônica de varredura e cortes histológicos observados em microscopia óptica. Com os resultados obtidos, esperamos obter uma melhor compreensão da ontogênese dos órgãos florais em Caesalpinia e comparar os eventos morfogenéticos observados em $C$. echinata com os observados em outras espécies da subfamília Caesalpinioideae, como Caesalpinia peltophoroides e Caesalpinia ferrea var. leyotachia. 


\section{REVISÃO DE LITERATURA}

\subsection{Relações filogenéticas na família Fabaceae}

A família Fabaceae é a terceira maior família das angiospermas (Chase et al. 1993; Doyle 1994; Chappill 1995). Compreende aproximadamente 700 gêneros e 18.000 espécies (Polhill \& Raven, 1981), dentre as quais muitas possuem importância econômica (Tucker, 2003).

Três subgrupos são geralmente reconhecidos dentro da família Fabaceae: Caesalpinioideae, Mimosoideae e Faboideae (Tabela 1). Na maior parte das classificações (Polhill et al., 1981; Judd et al, 1999) estes são considerados subfamílias, mas são muitas vezes tratados como famílias separadas (Cronquist, 1981; Dahlgren, 1983).

Neste trabalho, escolhemos seguir a filogenia sugerida por Judd et al., (1999) por se tratar de uma classificação baseada em dados morfológicos e de análises moleculares de seqüências de DNA. 
Tabela 1. Características para a classificação das subfamílias em Fabaceae (Judd et al, 1999)

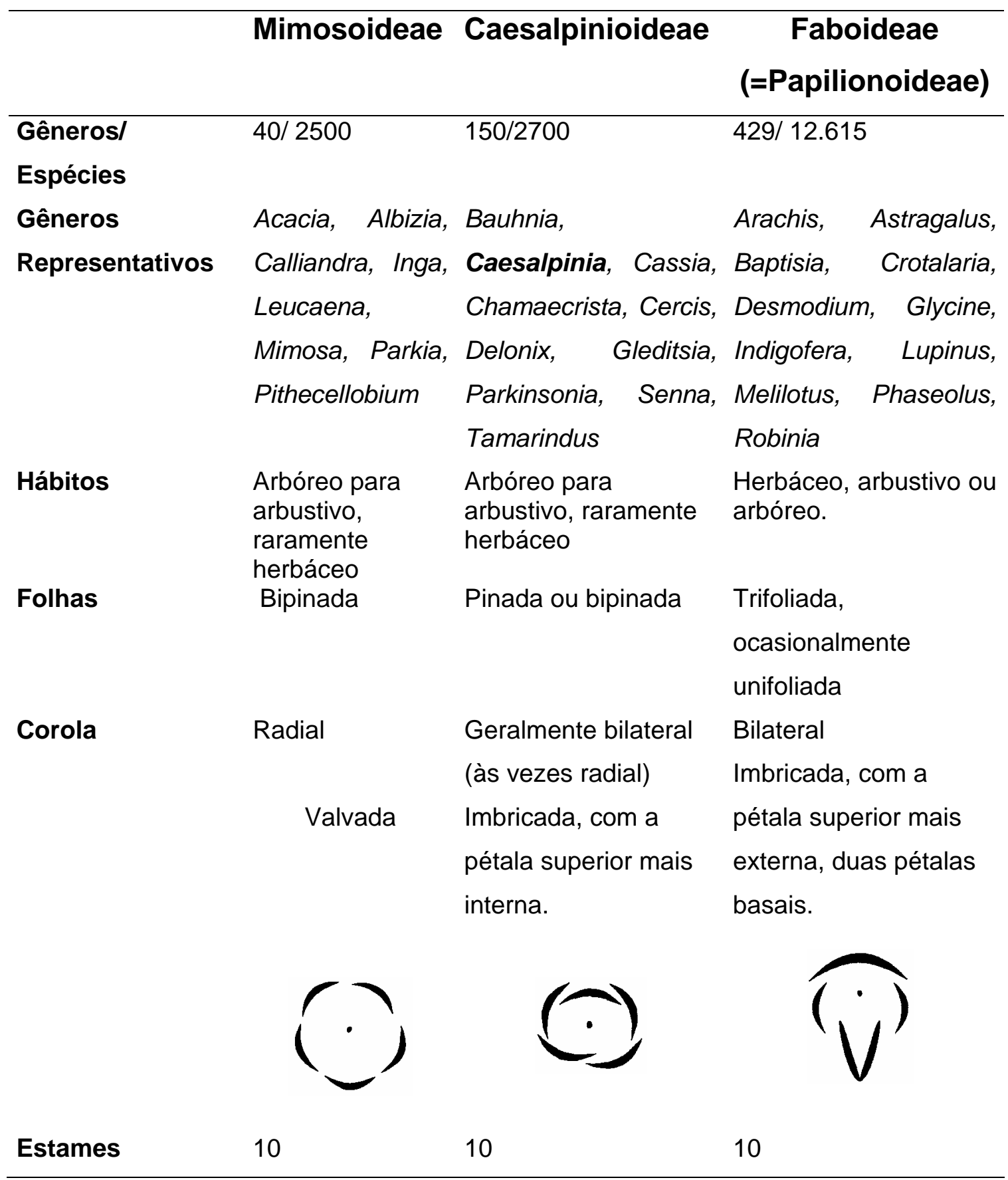


$\mathrm{Na}$ subfamília Mimosoideae encontram-se 65 gêneros e aproximadamente 3.000 espécies (Chappill, 1995). A subfamília Faboideae é a maior com 455 gêneros e aproximadamente 12.000 espécies (Chappill, 1995). Já a subfamília Caesalpinioideae é formada por 170 gêneros e aproximadamente 3.000 espécies (Doyle, 1995; Doyle et al., 2000, Bruneau et al., 2001), sendo extremamente diversa em morfologia e ontogenia floral (Tucker, 2003), compartilhando algumas das características de Mimosoideae e de Faboideae.

A subfamília Caesalpinioideae é atualmente dividida em cinco tribos: Cercideae, Caesalpinieae, Cassieae, Detarieae e Macrolobieae (Bruneau et al., 2001; Tucker et al., 2003).

Análises filogenéticas moleculares e de caracterização morfológica (Doyle, 1995; Doyle et al., 2000) mostraram que as subfamílias Faboideae e Mimosoideae são totalmente monofiléticas (Doyle et al., 2000; Kajita et al., 2001; Wojciechowski, 2003) já a subfamília Caesalpinioideae é polifilética, com alguns gêneros mais próximos a Mimosoideae e outros mais relacionados a Faboideae (Lavin, 1987). Apenas uma das tribos de Caesalpinioideae (Cercideae) aparenta ser monofilética (Bruneau et al., 2001).

Na tribo Caesalpineae da subfamília Caesalpinioideae, encontra-se o gênero Caesalpinia, que contém um total de 120 espécies, dentre elas $C$. echinata, C. peltophoroides e C. ferrea, objetos deste estudo.

C. echinata, conhecida como pau-brasil possui porte arbóreo, podendo alcançar até 30 metros de altura. Possuindo inflorescências localizadas nos 
ramos terminais com flores amarelas muito perfumadas. Seus frutos são do tipo vagem, possuindo deiscência explosiva e são totalmente recobertos por acúleos que se formam logo após a floração. Sua ocorrência é de floresta estacional semidecidual (Carvalho, 1994). Atualmente há evidências de que sua distribuição geográfica está restrita à costa ocidental atlântica brasileira, porém não se sabe ao certo sua freqüência ao longo desta área, devido à drástica redução das populações pela exploração predatória (Corrêa, 2003). Segundo Lima (1992), acredita-se que C. echinata era amplamente dispersa em todas as regiões da costa brasileira, pelo menos no trecho entre Rio de Janeiro e Rio Grande do Norte. Nos últimos 10 anos foram constatadas ocorrências de populações remanescentes nos estados do Rio Grande do Norte, Paraíba, Pernambuco, Alagoas, Bahia, Espírito Santo, Rio de Janeiro e São Paulo (Lima, 1992).

C. peltophoroides (sibipiruna) é uma espécie arbórea que atinge altura máxima em torno de 18 metros sendo muito confundida com o pau-brasil, pela semelhança do caule e de sua folhagem (Lorenzi, 2002). A sibipiruna perde parcialmente suas folhas no inverno e a floração ocorre de setembro a novembro, com as flores amarelas dispostas em cachos cônicos. Os frutos são de cor bege-claro, achatados, medindo cerca de $3 \mathrm{~cm}$ de comprimento e permanecem na árvore até abril (Lorenzi, 2002). Esta árvore é muito utilizada em paisagismo urbano em geral, sendo também indicada para projetos de reflorestamento pelo seu rápido crescimento e grande poder germinativo. A 
floração de C. peltophoroides ocorre geralmente 8 anos após a semeadura (Lorenzi, 2002).

Caesalpinia ferrea var. leiotachya (pau-ferro) é uma espécie arbórea com altura de 20-30m, tronco liso e escuro, apresentando algumas manchas brancas irregulares, característica que a difere da variedade ferrea. Sua ocorrência se dá do Piauí até São Paulo na floresta estacional semidecidual, floresta ombrófila densa e caatinga. Floresce a partir de novembro até fevereiro apresentando flores amarelas dispostas em cachos cônicos. Com frutos de cor preta. Sua madeira é muito empregada na construção civil como vigas e caibros (Lorenzi, 2000).

\subsection{Desenvolvimento floral em Fabaceae/ Caesalpinioideae}

Em plantas modelo para estudos de desenvolvimento floral, como Arabidopsis thaliana (família Brassicaceae) que possui flores organizadas em uma inflorescência (Koorneef et al., 1991), existem duas transições meristemáticas: uma para formar o meristema das inflorescências e outra para produzir os meristemas florais. As duas transições são processos distintos que podem ser separados geneticamente (Coen et al., 1991; Bradley et al., 1997). Diferentes tipos de inflorescências são formadas em espécies determinadas e indeterminadas (Vaughan, 1955). Em espécies determinadas, o meristema da inflorescência forma flores terminais, que finaliza qualquer crescimento futuro da inflorescência (Weigel et al., 1992; Baum, 1998). Em espécies 
indeterminadas as inflorescências formam-se em ramos laterais e não há formação de flores terminais (Coupland, 1995; Bradley et al., 1997).

Na subfamília Caesalpinioideae as inflorescências são geralmente racemos ou panículas embora sejam também observadas flores solitárias em algumas espécies (Tucker, 2003). Estas inflorescências possuem um meristema apical terminal que se desenvolve indeterminadamente, iniciando brácteas acropetalarmente ao longo do eixo da inflorescência. Um único meristema floral é geralmente iniciado na axila de cada uma destas brácteas (Tucker, 2003).

As flores da família Fabaceae são extremamente variáveis em tamanho, forma, cor e tipo de polinização. Os polinizadores podem ser abelhas, vespas, formigas, borboletas, besouros, pássaros e morcegos, entretanto a polinização por abelhas é a mais comum (Arroyo, 1981). Muitos gêneros de Fabaceae mostram processos coevolutivos com algumas espécies de formigas. As glândulas de néctar extraflorais são muito comuns em Mimosoideae e Caesalpinioideae (McKey, 1989).

A maioria das flores de leguminosas são pentâmeras e apresentam 5 sépalas e 5 pétalas, com 1 pétala que se destaca das demais por sua coloração diferente. A função desta pétala é a atração visual dos polinizadores (Judd et al., 1999). As flores de leguminosas possuem ainda 2 verticilos com 5 estames cada e um único carpelo, perfazendo 21 órgãos florais no total (Tucker, 1987; 2003). 
A posição dos órgãos florais difere entre as subfamílias. Em Caesalpinioideae, o verticilo de sépalas, o de pétalas e os dois verticilos de estames são pentâmeros e alternados. Esta distribuição da posição dos órgãos florais de Caesalpinioideae é semelhante à de Faboideae, mas difere da de Mimosoideae (Tucker, 2003).

As flores da subfamília Mimosoideae possuem simetria radial. Em muitas das espécies de Faboideae e Caesalpinioideae a simetria floral é bilateral (Tucker \& Douglas, 1994; Doyle, 1995; Tucker, 1999; Doyle et al., 2000; Doyle, 2003).

O estudo do desenvolvimento floral das espécies $C$. echinata, $C$. peltophoroides e C. ferrea pode auxiliar no esclarecimento dos eventos evolutivos dos membros da subfamília Caesalpinioideae. O desenvolvimento floral em leguminosas tem sido amplamente documentado (ver revisão de Tucker, 2003).

Membros da tribo Caesalpinieae (Polhill \& Raven, 1981; Kantz, 1996) são caracterizados por uma organização floral simples, simetria radial primária e uma falta de especializações. Esta falta de características florais especializadas pode ser considerada com um estado primitivo. A ontogenia floral é relativamente uniforme entre os membros da tribo Caesalpinieae (Tucker, 1984a; 1991; Kantz, 1996). De acordo com Kantz (1996), as especializações dos órgãos florais são raras nesta tribo. Recentes análises filogenéticas (Doyle, 1995; Doyle et al., 2000; Bruneau et al., 2001) sugerem que a tribo Caesalpinieae não é monofilética, como também a tribo Cassieae. 
Apenas Cercideae das tribos de Caesalpinioideae aparenta ser monofilética (Bruneau et al., 2001). As flores são geralmente apresentadas com simetria zigomorfa.

As tribos Detarieae e Macrolobieae contêm o maior número de espécies da subfamília Caesalpinioideae e, portanto são as mais estudadas. A estrutura floral nestas tribos é diversa, com numerosas especializações, incluindo a perda (aborto) natural de órgãos florais, logo após a iniciação dos mesmos (Tucker, 2000; 2001; 2002a), e perda de pétalas e de sépalas e uma conversão homeótica dos primórdios de pétalas em estames em Saraca diclinata (Tucker, 2000).

Em Caesalpinia pulcherrima, a simetria é zigomorfa, com iniciação de sépalas, pétalas e estames ocorrendo unidirecionalmente (Tucker et al., 1985).

Os gêneros Bauhinia, Gleditsia e Ceratonia possuem inflorescências do tipo racemo, simetria radial e a iniciação dos primórdios dos óvulos não ocorrem durante o estágio em que o gineceu ainda não se soldou (Tucker, 1991; Tucker, 1988; Kantz \& Tucker, 1994; Kantz, 1996).

As espécies do gênero Haematoxylum são muito similares no desenvolvimento floral inicial, possuindo inflorescências indeterminadas. A primeira sépala a se iniciar é a mediana, ao contrário do que se observa em outros gêneros de Caesalpinioideae (Kantz, 1996; Tucker, 1996).

Nos gêneros Amherstia, Brownea e Tamarindus são observadas inflorescências com diferenciação floral acropetalar. A simetria floral é 
zigomorfa, em Amherstia e Tamarindus, mas Brownea apresenta simetria radial na antese.

A perda de órgãos florais durante a evolução dos gêneros é comumente observada na subfamília Caesalpinioideae. Tucker (1991) observou que a ausência de primórdios de órgãos florais em alguns gêneros, como Gledtsia e Ceratonia, torna a organogênese floral caótica. O mesmo foi observado em Achlys por Endress (1989). Nos gêneros Amherstia e Tamarindus, Tucker (2000) observou a ausência da sépala adaxial e de duas pétalas.

Em Microberlinia brazzavillensis, observa-se o início da formação das brácteas acropetalarmente, com simetria floral actinomorfa. A iniciação dos primórdios das sépalas é helicoidal, a dos primórdios das pétalas é unidirecional e a dos primórdios dos estames é bidirecional. Adicionalmente as anteras são basifixas quando da sua iniciação, mas tornam-se dorsifixas na antese (Tucker, 2002b).

Estes relatos da literatura ilustram a grande diversidade dos padrões de ontogênese floral em leguminosas, particularmente na subfamília Caesalpinioideae. 


\section{MATERIAL E MÉTODOS}

Para a análise do desenvolvimento floral de pau-brasil (Caesalpinia echinata), sibipiruna (Caesalpinia peltophoroides) e pau-ferro (Caesalpinia ferrea var. leyotachia) foram coletadas inflorescências e flores em diferentes estágios de desenvolvimento. As coletas de material vegetal foram realizadas durante os anos de 2002 e 2003, em áreas da Escola Superior de Agricultura "Luiz de Queiroz" (ESALQ), em Piracicaba. Nesta localidade, o florescimento de pau-brasil ocorre de setembro ao início de outubro, de sibipiruna de setembro a novembro, com pico de florescimento de ambas as espécies em outubro e de pau-ferro de novembro ao início de março.

Imediatamente após as coletas, os materiais foram fixados em paraformaldeído (4\% p/v), sob vácuo de $60 \mathrm{mmHg}$ por 30 minutos. As amostras permaneceram por 48 horas adicionais neste fixador a $4^{\circ} \mathrm{C}$. Posteriormente, as amostras foram desidratadas em concentrações crescentes de etanol (30\%, 40\%, 50\%, 60\% e 70\%), sendo mantidas durante 4 horas em cada diluição, e conservadas em etanol $70 \%$ a $4^{\circ} \mathrm{C}$ até o uso posterior. 
Também foram analisadas 20 inflorescências de C. echinata, C. peltophoroides e C. férrea distribuídas em 10 ramos de 20 plantas diferentes, para contagem do número de flores por inflorescência.

\subsection{Microscopia eletrônica de varredura (MEV)}

As amostras armazenadas em etanol 70\% foram desidratadas até etanol $100 \%$ como descrito na tabela 2. A seguir as amostras foram secas ao ponto crítico (equipamento Balzers - CPD 030) e dissecadas para evidenciar as estruturas a serem observadas, montadas em porta-espécimes apropriados usando fita adesiva dupla face e metalizadas com ouro coloidal (45 a 60nm) em

metalizador (equipamento Balzers - MED 010). O material foi observado e fotografado em microscópios eletrônicos de varredura (ZEISS modelo DSM 940 A e LEO $435 \mathrm{VP}$ ) operando entre 10 e 15KV. As fotografias digitais das observações foram obtidas utilizando-se os programas DIT e LEO/UIF, no Núcleo de Apoio a Pesquisa/Microscopia Eletrônica na Pesquisa Agropecuária - (NAP/MEPA) - ESALQ/USP.

\subsection{Microscopia óptica (MO)}

As amostras foram desidratadas em série etílica até etanol $100 \%$ e emblocadas utilizando o Kit Historesina (hidroxietilmetacrilato, Leica 
Heidelberg), seguindo-se as instruções do fabricante do Kit com algumas modificações (Tabela 02).

Tabela 02. Protocolo para infiltração e emblocagem em historesina, modificado de Rodrigues \& Wetzstein, (1998)

PRODUTOI PROCEDIMENTO

Etanol PA 100\%

Propanol PA 100\%

Butanol PA 100\%

$1 / 2$ parte de Historesina e $1 / 2$ parte de Propanol

2/3 parte de Historesina e1/3 parte de Propanol

Historesina pura
TEMPO MÍINIMO

2 tratamentos de $4 \mathrm{~h}$ cada

2 tratamentos de $4 \mathrm{~h}$ cada

2 tratamentos de $4 \mathrm{~h}$ cada

4 horas

4 horas

1 semana

A polimerização da resina foi feita à temperatura ambiente por 48 horas. Cortes seriados com espessura de $5 \mu \mathrm{m}$ foram realizados em micrótomo rotativo (Leica - modelo RM2155), montados em lâminas histológicas e corados com azul de toluidina a $0,5 \%(p / v)$. Os cortes histológicos foram observados em Microscópio Zeiss Axiovert 35 e fotografados. 


\section{RESULTADOS}

\subsection{Estudo morfo-anatômico do desenvolvimento reprodutivo de Caesalpinia echinata}

O meristema da inflorescência de C. echinata iniciou a formação de meristemas florais acropetalarmente (figuras $1 \mathrm{~A}, \mathrm{C}$ ). $\mathrm{O}$ meristema da inflorescência manteve-se indeterminado, caracterizando um racemo.

Observou-se o número médio de $27 \pm 10$ (n=20) flores por inflorescência.

O meristema da inflorescência diferenciou brácteas protetoras na axila das quais formaram-se os meristemas florais (figura 2 A). As flores de $C$. echinata puderam ser descritas como completas, diclamídeas e pentâmeras, sendo compostas de cinco pétalas, cinco sépalas, dez estames e um carpelo. $\mathrm{Na}$ antese, observou-se a presença de sépalas e pétalas amarelas, com exceção da sépala verde abaxial e da pétala adaxial, que mostrou possuir uma mancha vermelho escuro (figura 1B).

Caesalpinia echinata pôde ser classificada como alógama, um padrão em Caesalpinioideae, por ter como características principais flores abertas e uma das pétalas coloridas, o que favorece a atração de polinizadores (figura 1 B). 

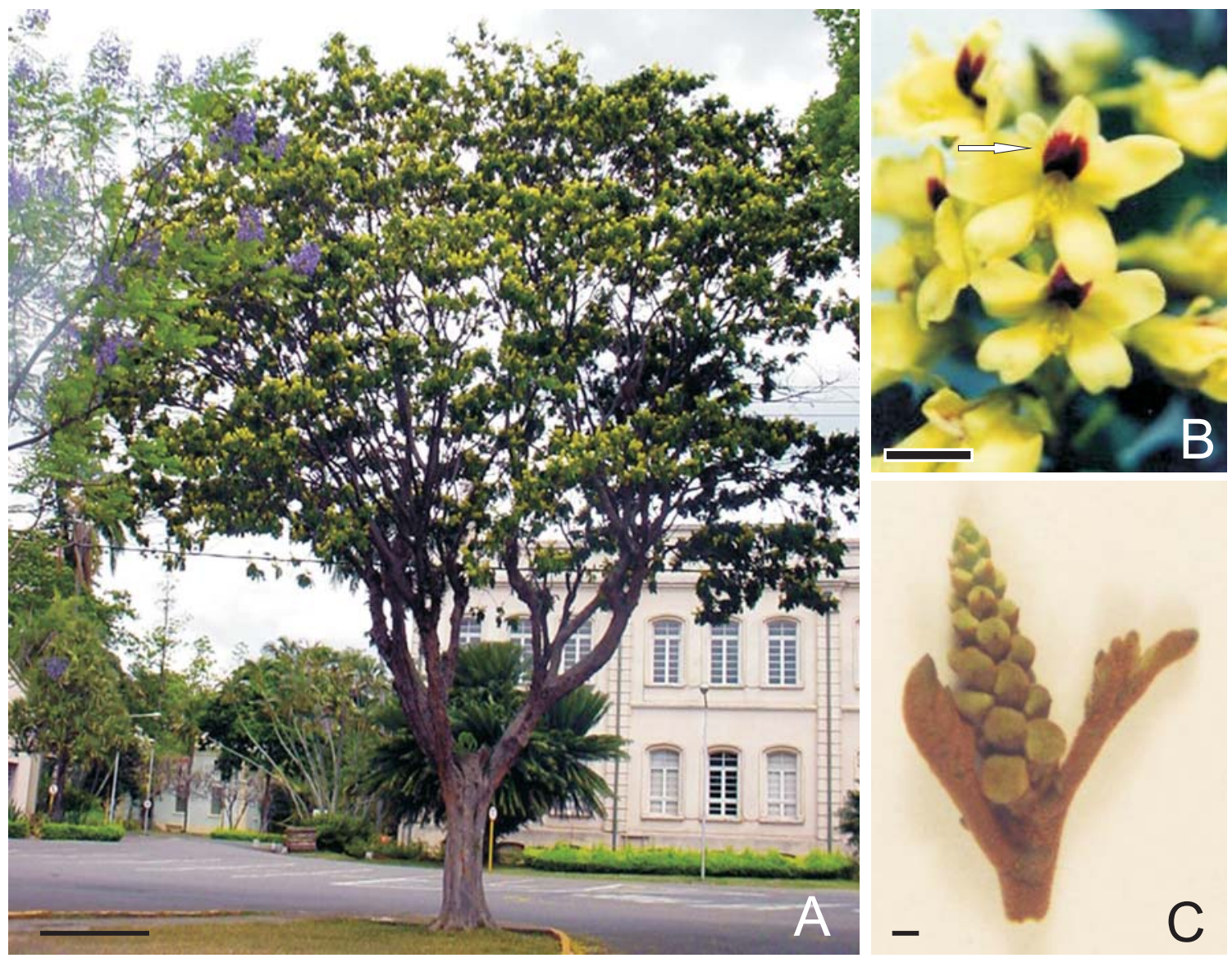

Figura 1 - Caesalpinia echinata Lam. A: Vista parcial do indivíduo adulto. B: Detalhe de um ramo, mostrando parte de uma inflorescência; duas flores na antese são mostradas em vista frontal, com a sépala abaxial, que é verde e a pétala adaxial, que possui uma mancha vermelho escuro (seta). C: Detalhe de uma inflorescência, contendo botões florais em diferentes estágios de desenvolvimento. Barras: A: $5 \mathrm{~m} ; \mathbf{B}: 1,5 \mathrm{~cm} ; \mathbf{C}: 2 \mathrm{~cm}$ 

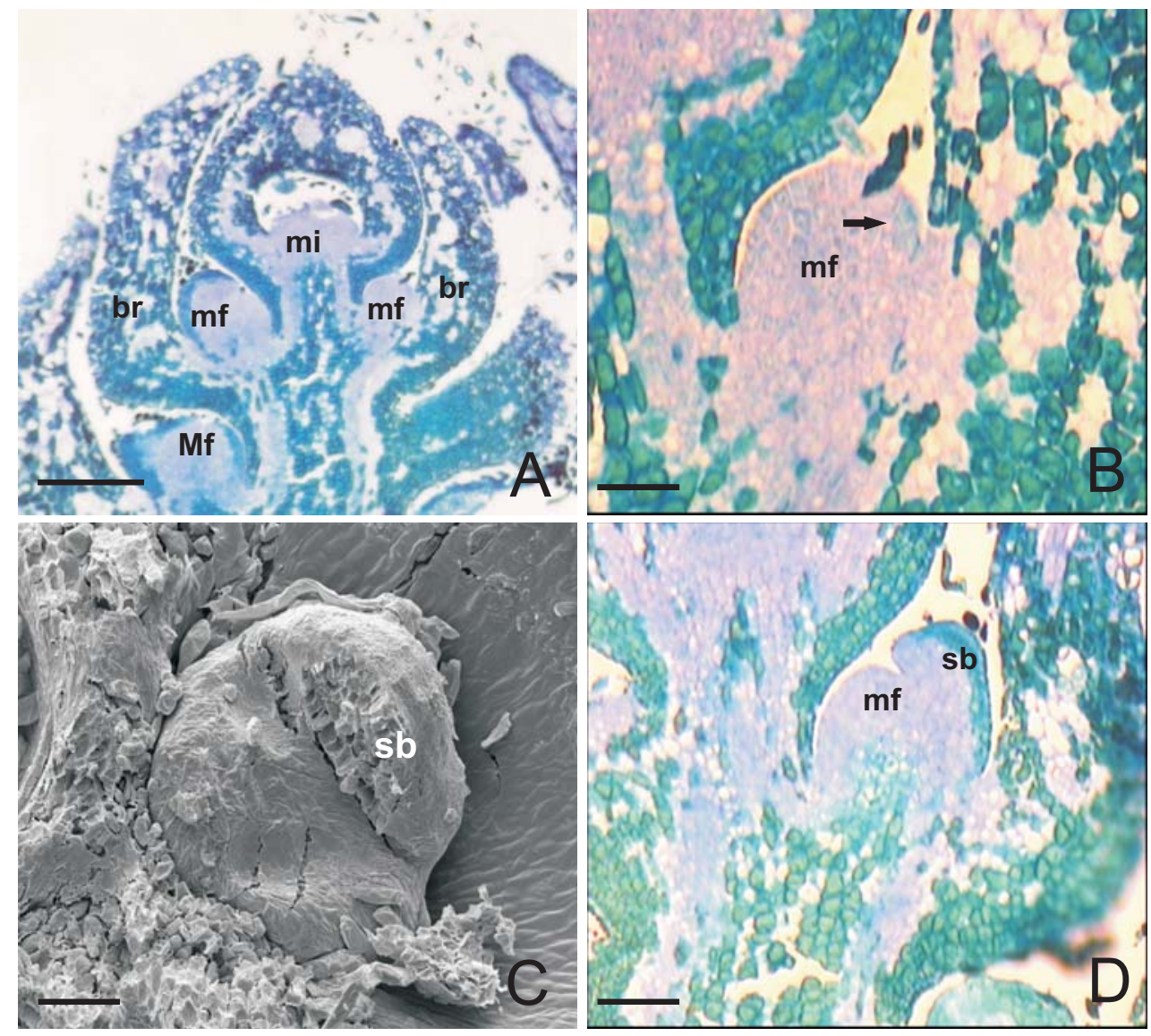

Figura 2 - Imagem de microscopia eletrônica de varredura (C) e de microscopia óptica (A, B, D) do desenvolvimento floral de Caesalpinia echinata Lam. A: Corte longitudinal de uma inflorescência mostrando os botões florais, protegidos por brácteas. B: Meristema floral, mostrando um pequeno acúmulo de compostos polifenólicos, onde haverá a formação da sépala (seta). C: Vista frontal do meristema com o início do desenvolvimento da sépala abaxial. D: Corte longitudinal do meristema floral. br: bráctea; mf: meristema floral; mi: meristema da inflorescência; sb: primórdio de sépala abaxial. Barras: A: $200 \mu \mathrm{m}$; B-D: $100 \mu \mathrm{m}$ 
primórdio da sépala abaxial foi o primeiro a ser iniciado a partir do meristema floral (figuras 2 B-D), seguido dos primórdios das sépalas laterais e adaxiais, formados unidirecionalmente (figuras $3 \mathrm{~A}-\mathrm{C}$ ).

Observou-se a presença de células coradas fortemente em verde, na região abaxial dos primórdios de sépalas, quando o corante azul de toluidina foi utilizado (figuras 3 A, C, D). Segundo O'Brien et al., (1964), o corante policromático azul de toluidina cora em verde alguns compostos polifenólicos, como a lignina. No entanto quando cortes frescos contendo materiais equivalentes aos descritos acima foram corados com uma solução saturada de phloroglucinol (Trump, 1961; Yanovsky, 2003), a reação histoquímica para a presença de lignina foi negativa.

Os primórdios das pétalas diferenciaram-se de forma unidirecional, sendo o primórdio da pétala adaxial o primeiro a ser iniciado (figuras $3 \mathrm{D}, \mathrm{E}$ ). Os primórdios de pétala não aumentaram de tamanho até o início do desenvolvimento das anteras epissépalas.

Pouco antes da antese as pétalas mostraram-se imbricadas, ou seja, as margens das pétalas são superpostas, havendo uma pétala totalmente externa 

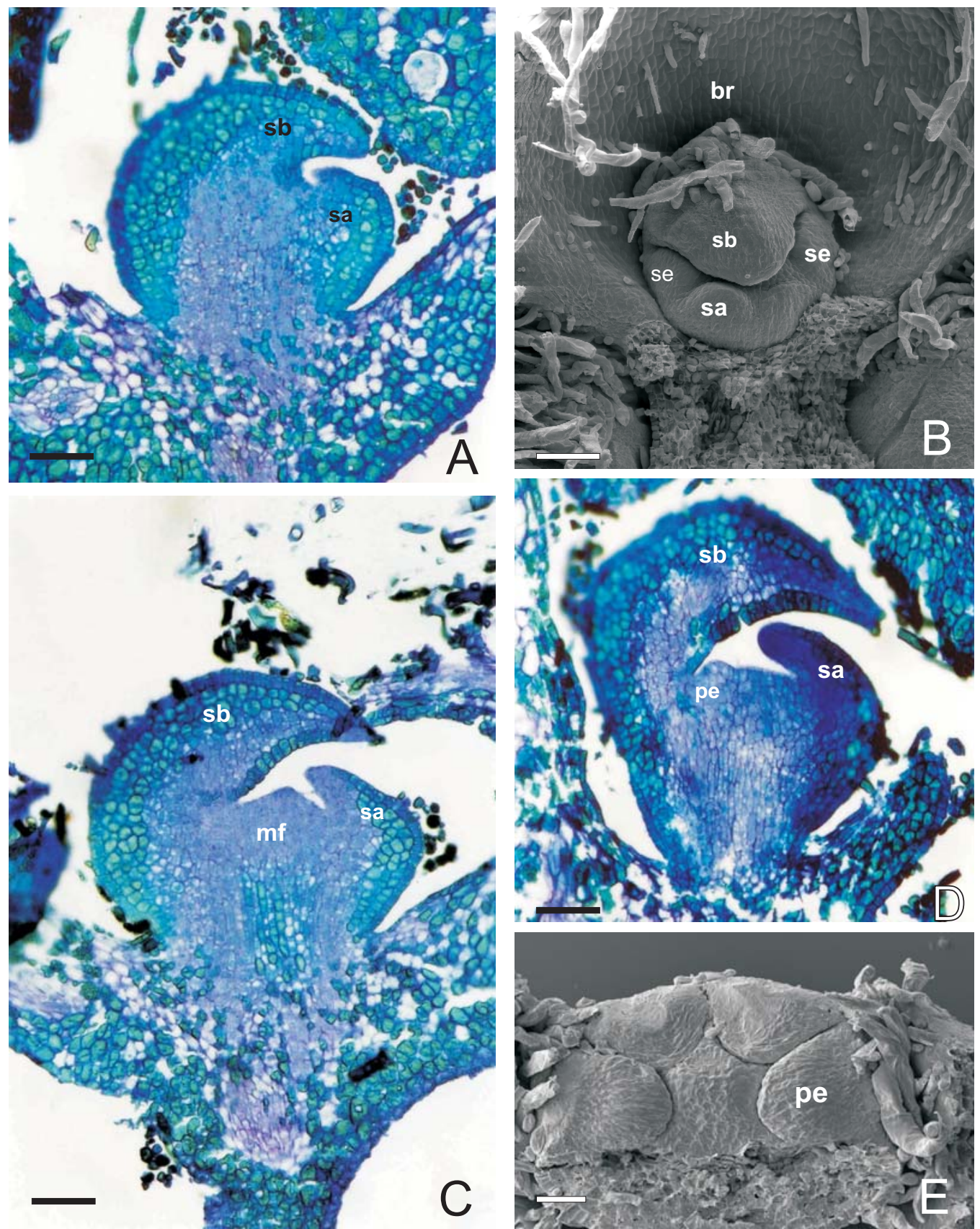

Figura 3 - Imagem de microscopia eletrônica de varredura (B, E) e de microscopia óptica (A, C, D) do desenvolvimento floral de Caesalpinia echinata Lam. A: Corte longitudinal do meristema floral, mostrando a formação do primórdio das sépalas abaxial e adaxial e o acúmulo de compostos polifenólicos na face abaxial dos mesmos. B: Meristema floral em vista frontal no estágio de diferenciação dos primórdios das sépalas. C: Corte longitudinal do meristema floral no estágio de diferenciação dos primórdios das sépalas. D: Início da formação do primórdio da pétala. E: Vista frontal do meristema floral indicando o desenvolvimento do primórdio das pétalas. br: bráctea; mf: meristema floral; pe: primórdio de pétala; sa: primórdio da sépala adaxial; sb: primórdio da sépala abaxial. Barras: A: $400 \mu \mathrm{m}$; B: $20 \mu \mathrm{m}$; C e D: $600 \mu \mathrm{m}$; E: $20 \mu \mathrm{m}$ 

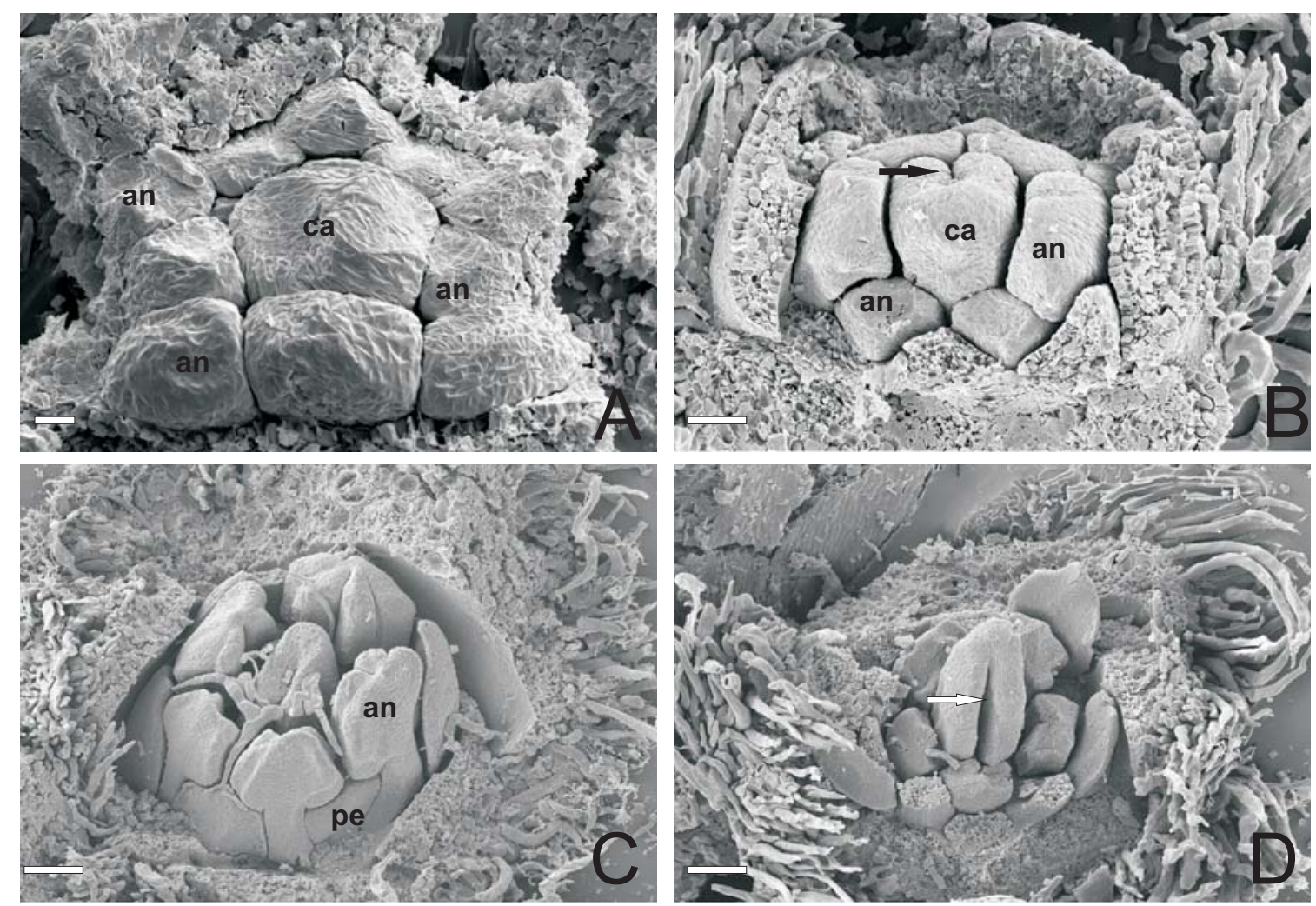

Figura 4 - Imagens de microscopia eletrônica de varredura do desenvolvimento floral de Caesalpinia echinata Lam. A: Meristema floral, em vista polar, no estágio de diferenciação dos 10 primórdios dos estames, podendo-se também observar o desenvolvimento do primórdio do carpelo, no centro do meristema floral. B: Meristema floral em estágio posterior ao mostrado em A. Notar o início da invaginação do lado adaxial (seta). C: Neste estágio quando ocorre a invaginação do lado adaxial do carpelo, nota-se o crescimento diferencial das anteras. D: A invaginação forma uma fenda cuja superfície interna originará a placenta (seta). ca: primórdio do carpelo; es: estame; pe: primórdio de pétala. Barras: A: $10 \mu \mathrm{m}, \mathbf{B}$ - D: $30 \mu \mathrm{m}$ 
e uma totalmente interna. A pétala interna foi distinta das demais, por possuir uma mancha vermelho escuro. A distinção clara de uma pétala em particular, em relação às demais, é uma característica comum nas flores da subfamília Caesalpinioideae.

Os primórdios das anteras epissépalas foram iniciados a seguir (figuras 4 A, B), simultaneamente em dois verticilos concêntricos. No verticilo externo (anteras epissépalas) originam-se os primórdios maiores $(60 \mu \mathrm{m}$, em média, na formação), e no verticilo interno (anteras epipétalas) formaram-se primórdios menores $(35 \mu \mathrm{m}$, em média, na formação).

O alongamento dos estames epipétalos ocorre apenas quando o carpelo iniciou a formação do sulco longitudinal que originará a placenta (figuras $4 C$, D).

As anteras classificaram-se como dorsifixas, sendo a abertura das mesmas do tipo longitudinal (figuras 5 A-D), promovendo a liberação dos grãos de pólen (figura $5 \mathrm{E}$ ).

Os grãos de pólen de pau-brasil mostraram-se de médios a grandes, com âmbito circular, 3-brevicolporados com diâmetro polar de 46,3 $\pm 0,5 \mu \mathrm{m}$. Recentemente, Corrêa (2003) publicou uma descrição detalhada do pólen de pau-brasil, confirmando as nossas análises (figura $5 \mathrm{~F}$ ).

A formação do gineceu iniciou-se com uma protuberância no centro do meristema floral (figura 4 A), antes que os primórdios dos estames epipétalos alongarem-se. Quando o primórdio do carpelo atingiu cerca de $100 \mu \mathrm{m}$ de 

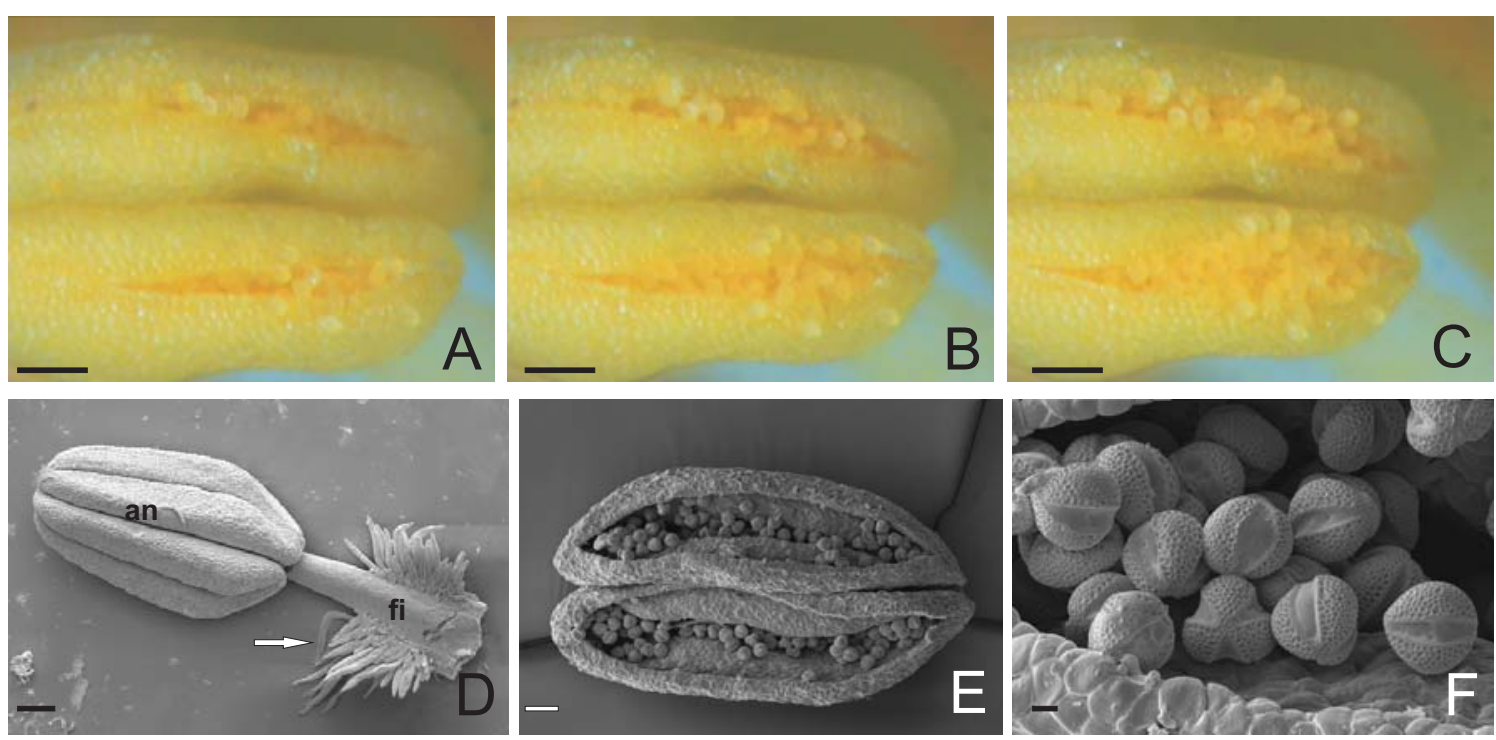

Figura 5 - Fotos em lupa (A, B, C) e de microscopia eletrônica de varredura (D, E, F) de Caesalpinia echinata Lam. A, B, C: Fotomicrografias, tiradas a 5 minutos de intervalo, mostrando a mesma antera de $C$. echinata, em estágio de liberação dos grãos de pólen. D: Imagem de um estame, mostrando as aberturas longitudinais e tricomas na base do filete (seta). E: Imagem de uma antera, cortada transversalmente, mostrando grãos de pólen no seu interior. F: Grãos de pólen de C. echinata. an: estame, fi: filete Barras: A, B, C: $300 \mu \mathrm{m}$; D, E: $100 \mu \mathrm{m} ; \mathrm{F}: 10 \mu \mathrm{m}$ 
altura, iniciou-se uma invaginação em seu lado adaxial (figura 4 B). Esta invaginação formou uma fenda, na superfície interna da qual foi formada a placenta (figuras 4 D; 6 A, B) e, posteriormente, os primórdios dos óvulos (figura $6 \mathrm{D}, \mathrm{F})$.

O ovário, estilete e estigma foram formados pela fusão pós-genital do carpelo (figura $6 \mathrm{C}, \mathrm{E})$.

As células da região estigmática se diferenciaram em células papilares alongadas e estas se curvaram para o lado adaxial (inserto fig. 7 A). Observouse igualmente um alongamento do estilete de $C$. echinata à medida que a flor se aproximou da antese (figuras 6 E, F; 7 A-C). Este alongamento do estilete, proporcionalmente ao tamanho do ovário, é uma característica da subfamília Caesalpinioideae (Tucker, 1999).

$\mathrm{Na}$ região interna do complexo estigma/ estilete observou-se uma epiderme com células alongadas. Os grãos de pólen germinaram nesta região ou sobre as células papilares (figura 7 D, E).

A característica zigomorfa das flores de C. echinata foi expressa quando as pétalas e estames iniciaram um alongamento diferencial tardiamente durante o seu desenvolvimento. 

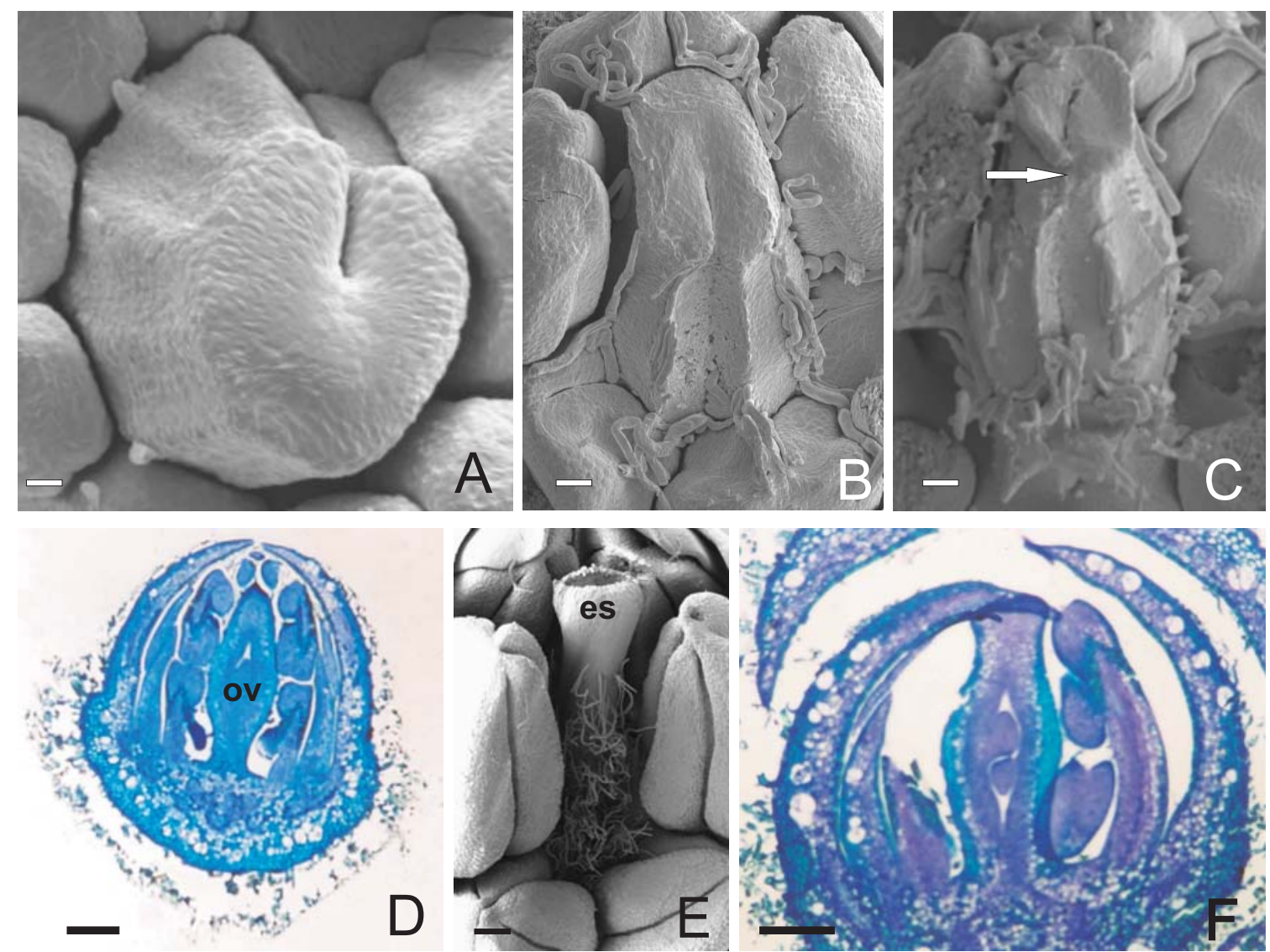

Figura 6 - Imagens de microscopia eletrônica de varredura (A, B, C, E) e de microscopia óptica (D, F) de C. echinata Lam. A: Carpelo em desenvolvimento no qual se observa a fenda placentária. B: Gineceu em estágio de desenvolvimento posterior ao mostrado em A. Notar o alongamento diferencial do lado abaxial. C: Gineceu com início da fusão pósgenital (seta). D: Corte longitudinal do meristema floral, onde nota-se a regiào placentária. E: As células da região estigmática se diferenciam em células papilares alongadas. F: Nota-se um alongamento do estilete a medida que a flor se aproxima da antese, e a formação do primórdio dos óvulos. es: estigma, ov: ovário. Barras: A, B: $100 \mu \mathrm{m} ; \mathrm{C}: 30 \mu \mathrm{m} ; \mathrm{D}: 100 \mu \mathrm{m} ; \mathrm{E}: 200 \mu \mathrm{m} ; \mathrm{F}: 300 \mu \mathrm{m}$ 

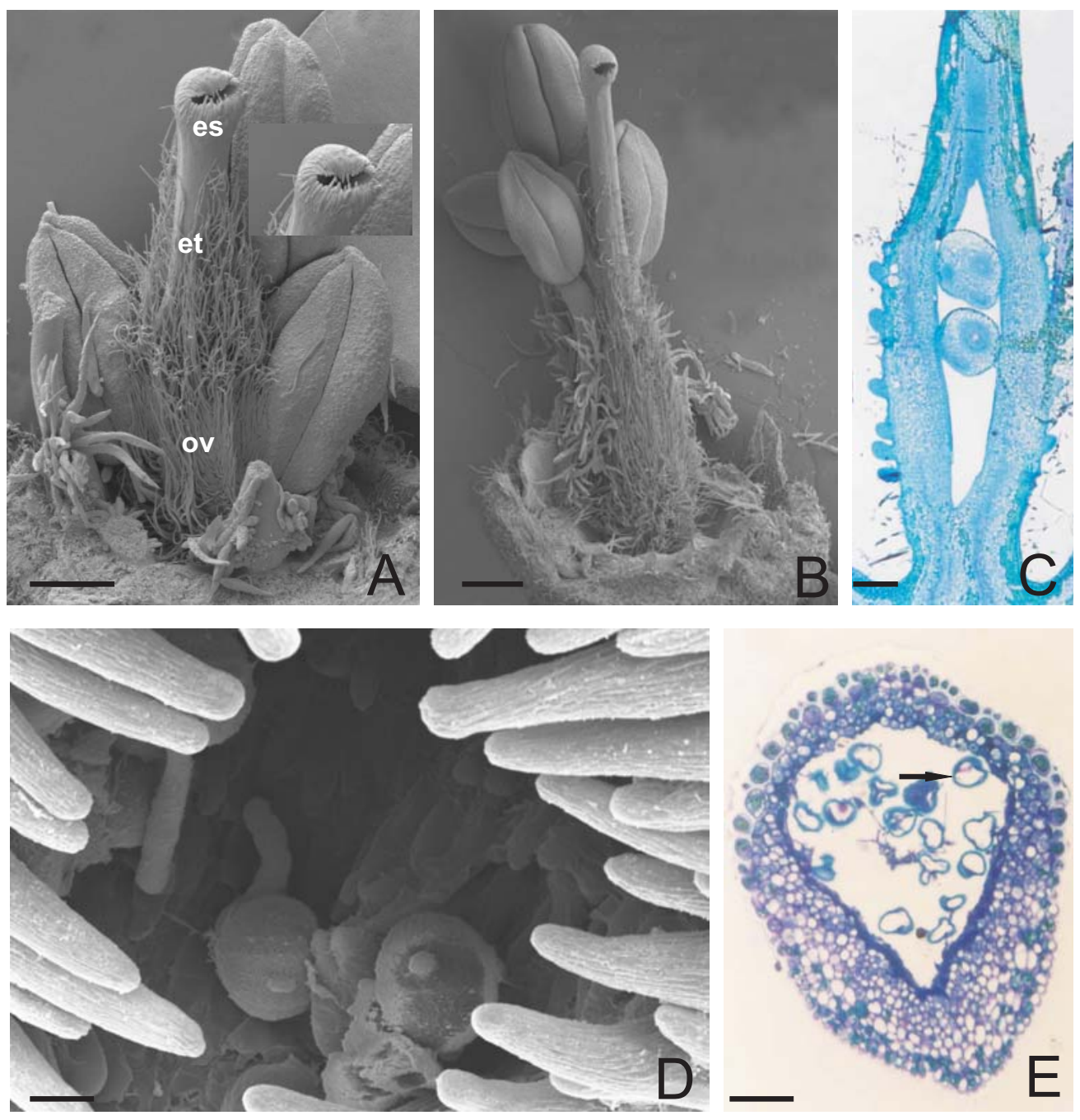

Figura 7- Imagens de microscopia eletrônica de varredura (A, B, D) e de microscopia óptica (C, E) de C. echinata Lam. A: Botão floral dissecado com o gineceu, mostrando o posicionamento da região estigmática com inclinação adaxial. B: Botão floral próximo a antese, notar tricomas na região do ovário e o alongamento dos estames epipétalos e epissépalos. C: Corte longitudinal do gineceu mostrando os óvulos e a região placentária. D: Região estigmática, onde nota-se grãos de pólen em estágio de germinação. E: Corte transversal da região estigmática, no mesmo estágio de $D$. Notar os grãos de pólen no interior da região estigmática (seta). es: estigma; et: estilete; ov: ovário. Barras: A: $200 \mu \mathrm{m} ; \mathrm{B}, \mathrm{C}: 300 \mu \mathrm{m} ; \mathrm{D}: 200 \mu \mathrm{m} ; \mathrm{E}: 200 \mu \mathrm{m}$ 


\subsection{Estudo morfo-anatômico do desenvolvimento reprodutivo de Caesalpinia peltophoroides}

As inflorescências de C. peltophoroides puderam ser classificadas como do tipo racemo, formada por flores hermafroditas, possuindo um meristema terminal apical, sendo considerada indeterminada. $O$ meristema da inflorescência produziu brácteas acropelarmente que cobrem e protegem os meristemas florais (figuras $8 \mathrm{C} ; 9 \mathrm{~A}, \mathrm{~B}$ ).

As flores de sibipiruna puderam ser classificadas como completas, diclamídeas e pentâmeras, sendo compostas de cinco pétalas, cinco sépalas, dez estames e um carpelo. Observou-se que a flor na antese possui sépalas e pétalas amarelas, com exceção da sépala verde abaxial e da pétala adaxial, que mostrou uma mancha vermelho claro (figuras $8 \mathrm{~A}, \mathrm{~B}$ ).

Observou-se o número médio de $27 \pm 10(n=20)$ flores por inflorescência.

Os primórdios das sépalas iniciaram-se unidirecionalmente, sendo o primórdio abaxial o primeiro a ser iniciado (figuras 9 C-E). Logo após a formação dos cinco primórdios de sépala, iniciou-se no segundo verticilo a formação unidirecional dos 5 primórdios de pétala (figura 9 F).

Após a formação do segundo verticilo, iniciou-se a formação dos primórdios das anteras epissépalas e epipétalas que mantiveram-se no mesmo tamanho dos primórdios das pétalas até o início da formação do gineceu (figura $9 \mathrm{~F}) . \mathrm{Na}$ antese todos os estames eram livres e as anteras dorsifixas, 


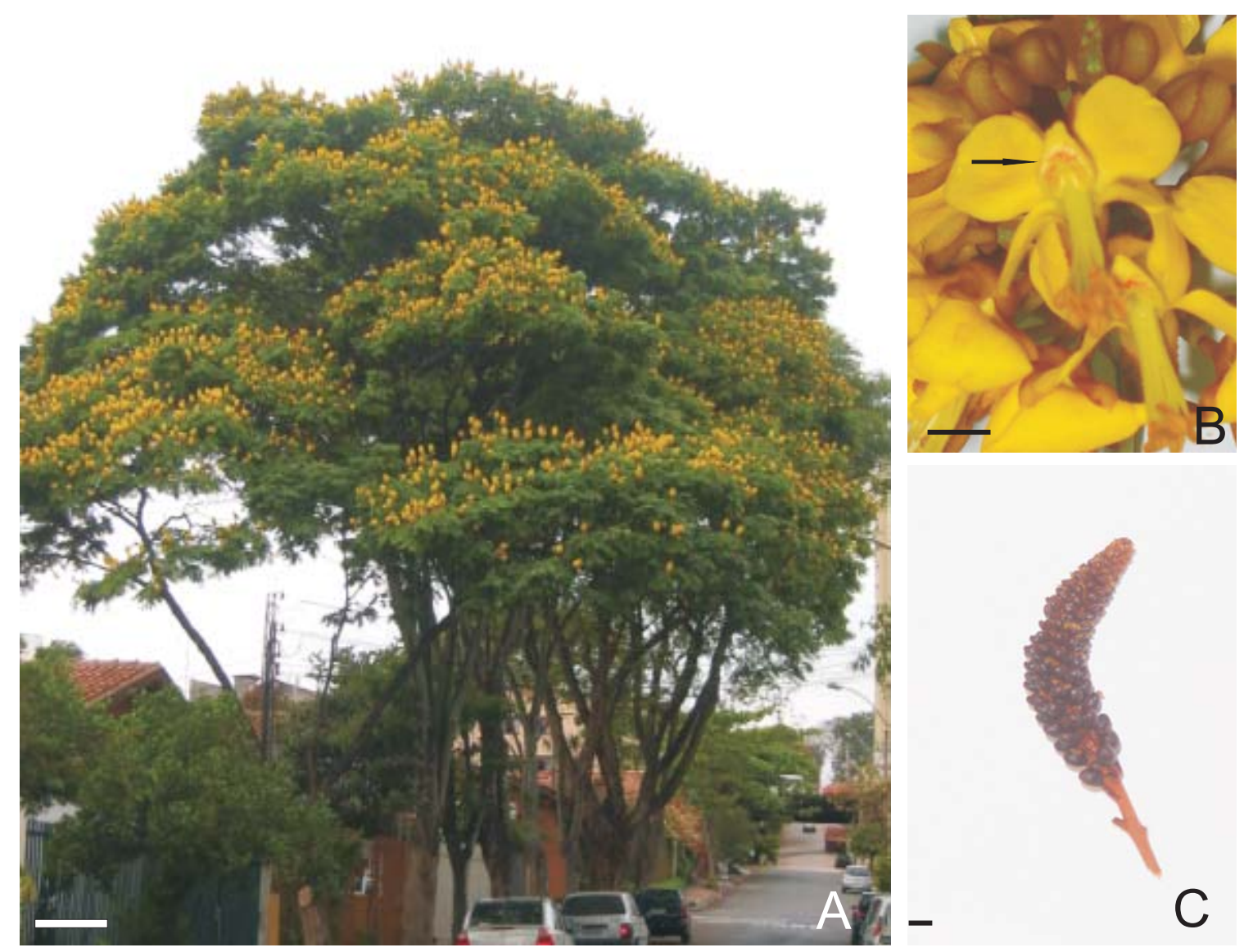

Figura 8 - Caesalpinia peltophoroides Benth. A: Vista parcial do indivíduo adulto. B: Flores na antese, a seta indica a pétala adaxial, com a coloração vermelho claro. C: Detalhe de uma inflorescência, com botões florais em diferentes estágios de desenvolvimento. Barras: A: $5 \mathrm{~m}, \mathrm{~B}: 1,5 \mathrm{~cm} ; \mathrm{C}: 3 \mathrm{~cm}$. 

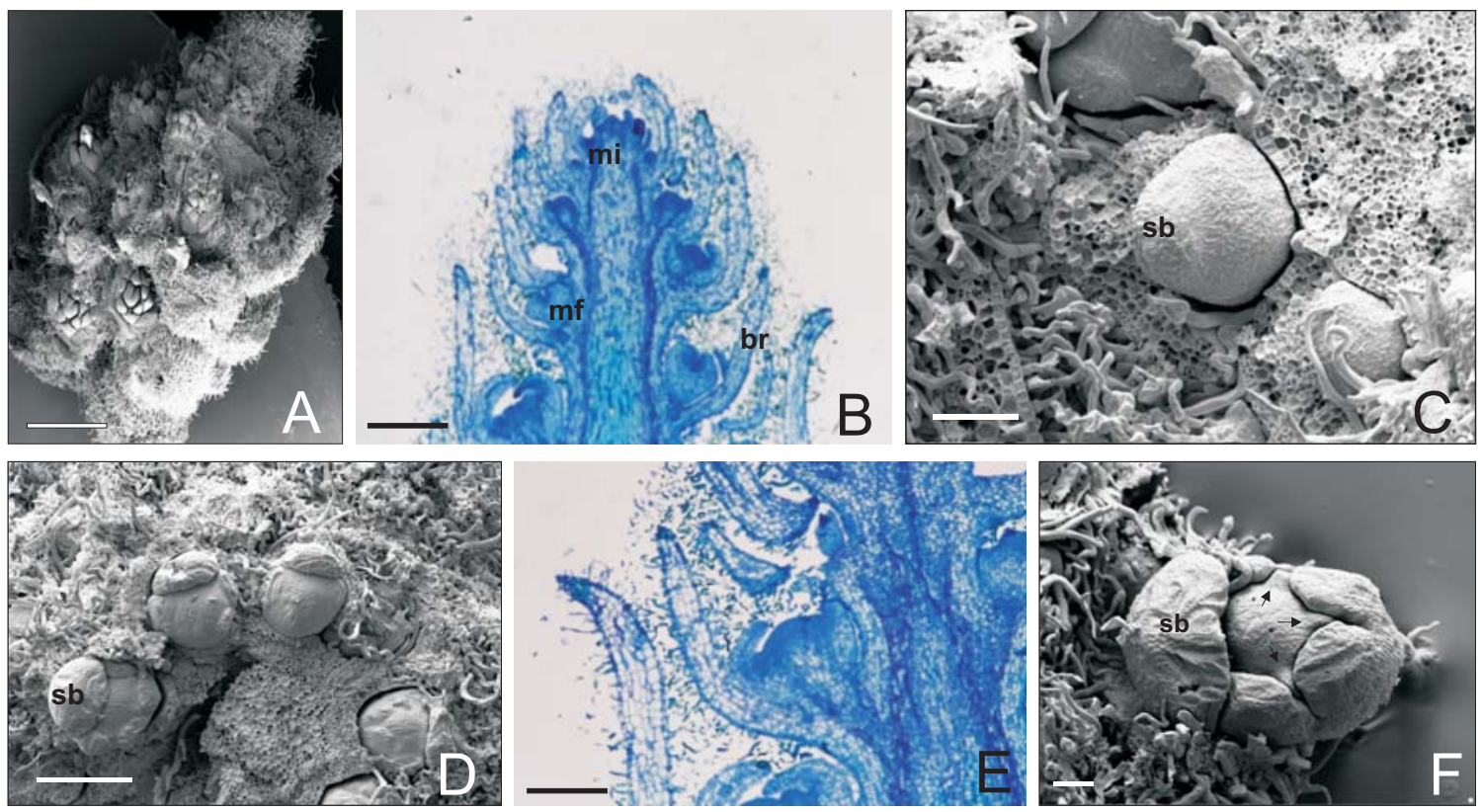

Figura 9 - Imagem de microscopia eletrônica de varredura (A, C, D, F) e de microscopia óptica (B, E) do desenvolvimento floral de Caesalpinia peltophoroides Benth. A: Inflorescência, mostrando meristemas florais em diferentes estágios de desenvolvimento. B: Corte de uma inflorescência mostrando os botões florais, o meristema da inflorescência e as brácteas. C, D: Meristemas florais em início de diferenciação do primórdio das sépalas. E: Corte longitudinal do meristema floral. F: Meristema floral onde as setas indicam o início da diferenciação do primórdio das pétalas. br: bráctea; mf: meristema floral; mi: meristema da inflorescência; sb: primórdio da sépala abaxial. Barras: A: ;B:100 $\mu \mathrm{m}$; D:200 $\mu \mathrm{m} ; \mathrm{E}: 100 \mu \mathrm{m} ; \mathrm{F}: 30 \mu \mathrm{m}$ 
possuindo abertura longitudinal para a liberação dos grãos de pólen (figuras 10 A, B). Os grãos de pólen de sibipiruna são médios, com âmbito circular, com

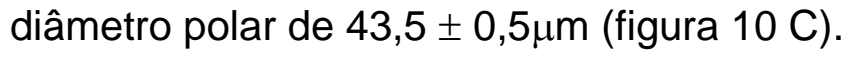

O primórdio do carpelo iniciou-se como uma pequena protuberância no centro do meristema floral. Uma vez que o mesmo atingiu a altura de aproximadamente $120 \mu \mathrm{m}$, foi possível observar o início de uma invaginação do lado adaxial do carpelo onde se deu início ao desenvolvimento dos primórdios dos óvulos (figuras 11 A, B, C). Durante o desenvolvimento do carpelo de sibipiruna, a região abaxial mostrou um crescimento diferenciado em relação à região adaxial, onde se deu a formação da placenta (figuras 11 D, E). A região interna da fenda formada pela invaginação do carpelo manteve-se aberta no início da formação do primórdio dos óvulos (figura 11 C).

Durante seu desenvolvimento o carpelo continuou a se alongar, sofrendo fusão pós-genital, para a formação do ovário, do estilete e do estigma (figuras $11 \mathrm{D}, \mathrm{E})$. Observou-se uma grande quantidade de tricomas na posição basal do carpelo e dos estames (figura $11 \mathrm{~F}$ ).

$\mathrm{Na}$ antese, o estigma apresentou-se na forma de um anel, contendo células papilares alongadas. Nesta região ou na parte interna do estigma ocorreu a germinação dos grãos de pólen (figuras 11 F). 

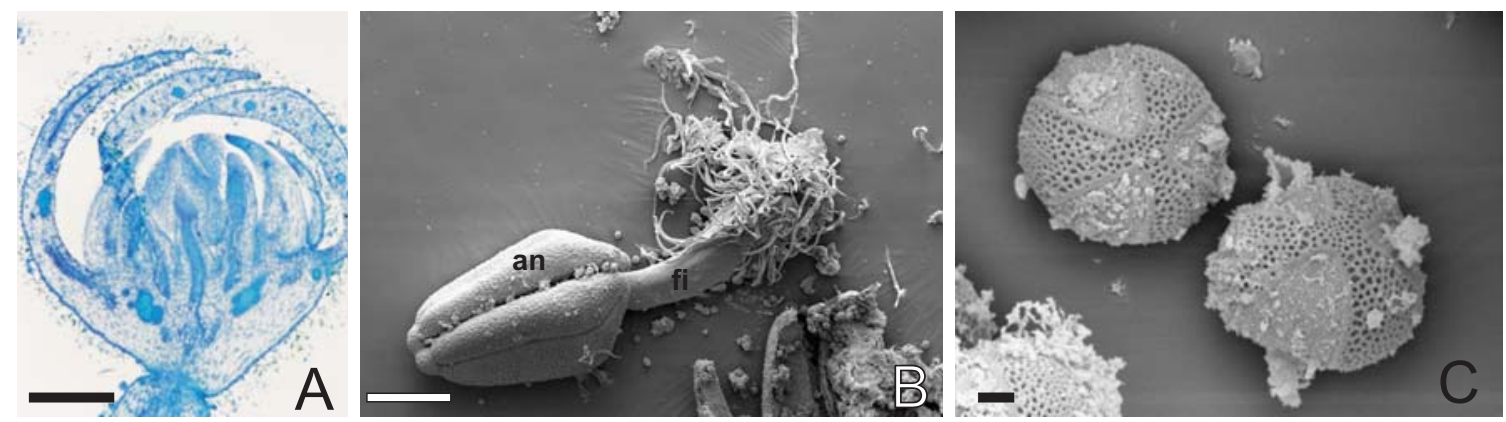

Figura 10 - Imagem de microscopia eletrônica de varredura (B, C) e de microscopia óptica (A) de Caesalpinia peltophoroides Benth. A: Corte longitudinal de uma flor, mostrando a ligação dorsifixa do estilete (seta). B: Imagem de um estame, mostrando abertura longitudinal e tricomas na base. C: Grãos de pólen de C. peltophoroides. an: antera; fi: filete. Barras: A, B: $100 \mu \mathrm{m}$; : $10 \mu \mathrm{m}$ 

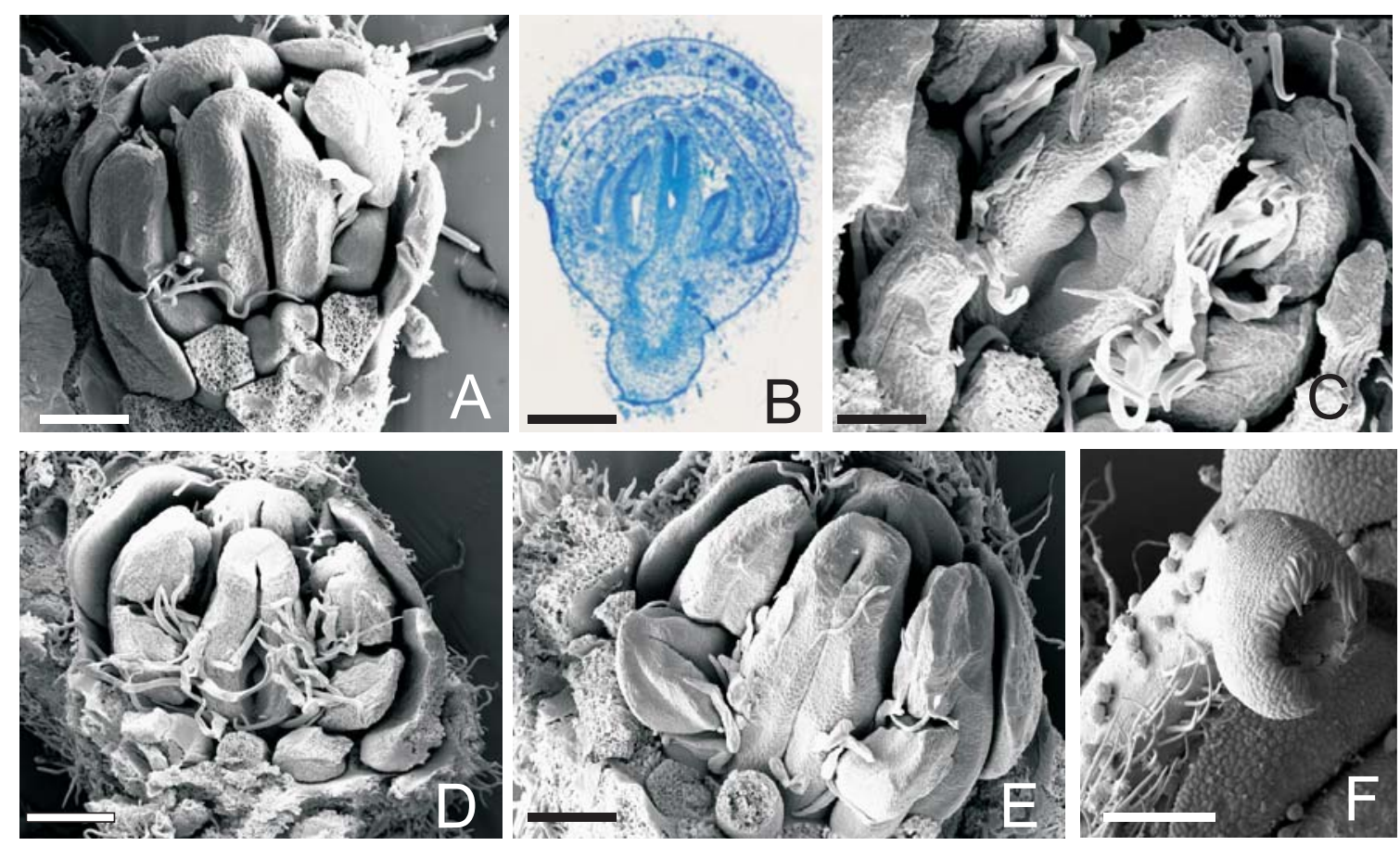

Figura 11 - Imagem de microscopia eletrônica de varredura (A, C, D, F) e de microscopia óptica (B) de Caesalpinia peltophoroides Benth. A: Meristema floral onde o sulco da região do carpelo ja está formado, originando a região da placenta. B, C: Meristema floral, onde nota-se o início do desenvolvimento do primórdio dos óvulos. D, E: Meristema floral durante as fases finais do desenvolvimento do gineceu. Notar o início da fusão pósgenital do carpelo. F: Gineceu proximo a antese, mostrando o curvamento da região estigmática. Barras: A-E: $100 \mu \mathrm{m}$; F: $200 \mu \mathrm{m}$ 


\subsection{Estudo morfo-anatômico do desenvolvimento reprodutivo de Caesalpinia ferrea var. leyotachia}

As inflorescências de pau-ferro, classificadas como racemos, foram formadas pelos meristemas das inflorescências. Estes produziram brácteas que cobriram os meristemas florais (figuras $12 \mathrm{C} ; 13 \mathrm{~A}, \mathrm{~B}$ ).

As flores de pau-ferro foram classificadas como completas, hermafroditas, diclamídeas e pentâmeras, sendo compostas de cinco pétalas,

cinco sépalas, dez estames e um carpelo. A flor na antese possuiu sépalas e pétalas amarelas, com exceção da pétala adaxial que mostrou pequenas manchas vermelho claro (figuras $12 \mathrm{~A}, \mathrm{~B}$ ).

Observou-se o número médio de $20 \pm 10(n=20)$ flores por inflorescência.

Os primórdios das sépalas desenvolveram-se unidirecionalmente, sendo o primórdio da sépala abaxial o primeiro a ser iniciado. Durante o seu desenvolvimento este primórdio cobriu o meristema floral (figuras $13 \mathrm{C}$-E).

Os primórdios das pétalas foram iniciados em ordem unidirecional, sendo o primórdio abaxial o primeiro a ser iniciado, seguido do primórdio das sépalas laterais e adaxial (figura 13 F). Uma vez que o primórdio da pétala adaxial foi formado, observou-se o início do desenvolvimento do primórdio dos estames.

Os primórdios dos estames abaxiais foram os primeiros a serem iniciados e assim que estes diferenciaram-se observou-se o início do 


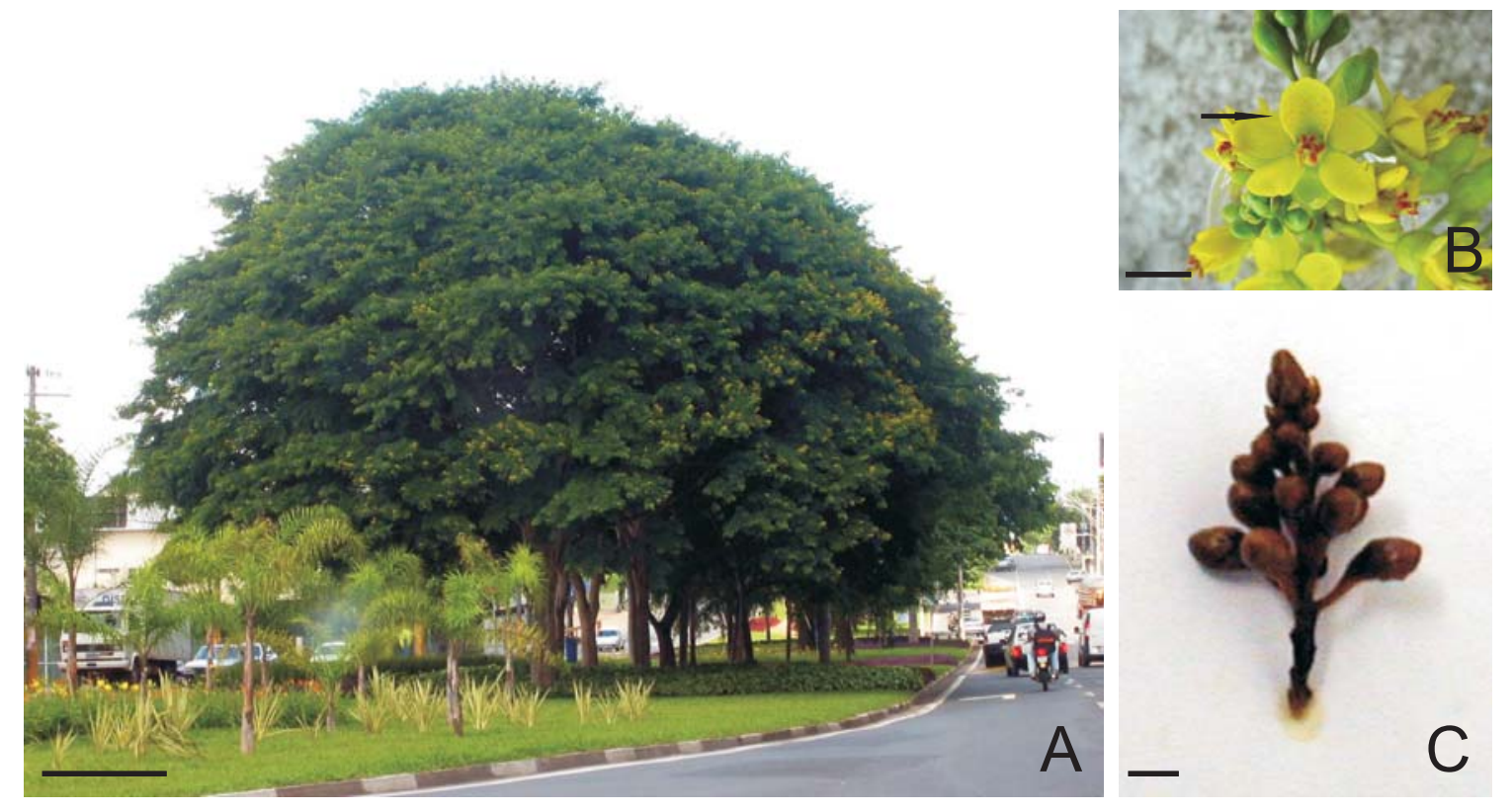

Figura 12 - Caesalpinia ferrea var leyotachia Benth. A: Vista parcial do indivíduo adulto. B: Detalhe de um ramo, mostrando parte de uma inflorescência; flores na antese são mostradas em vista frontal,, a sépala abaxial é verde e a pétala adaxial, que possui manchas vermelho claro (seta). C: Detalhe de uma inflorescência, contendo botões florais em diferentes estágios de desenvolvimento. Barras: A: $5 \mathrm{~m} ; \mathbf{B}: 1,5 \mathrm{~cm} ; \mathbf{C}: 2 \mathrm{~cm}$ 

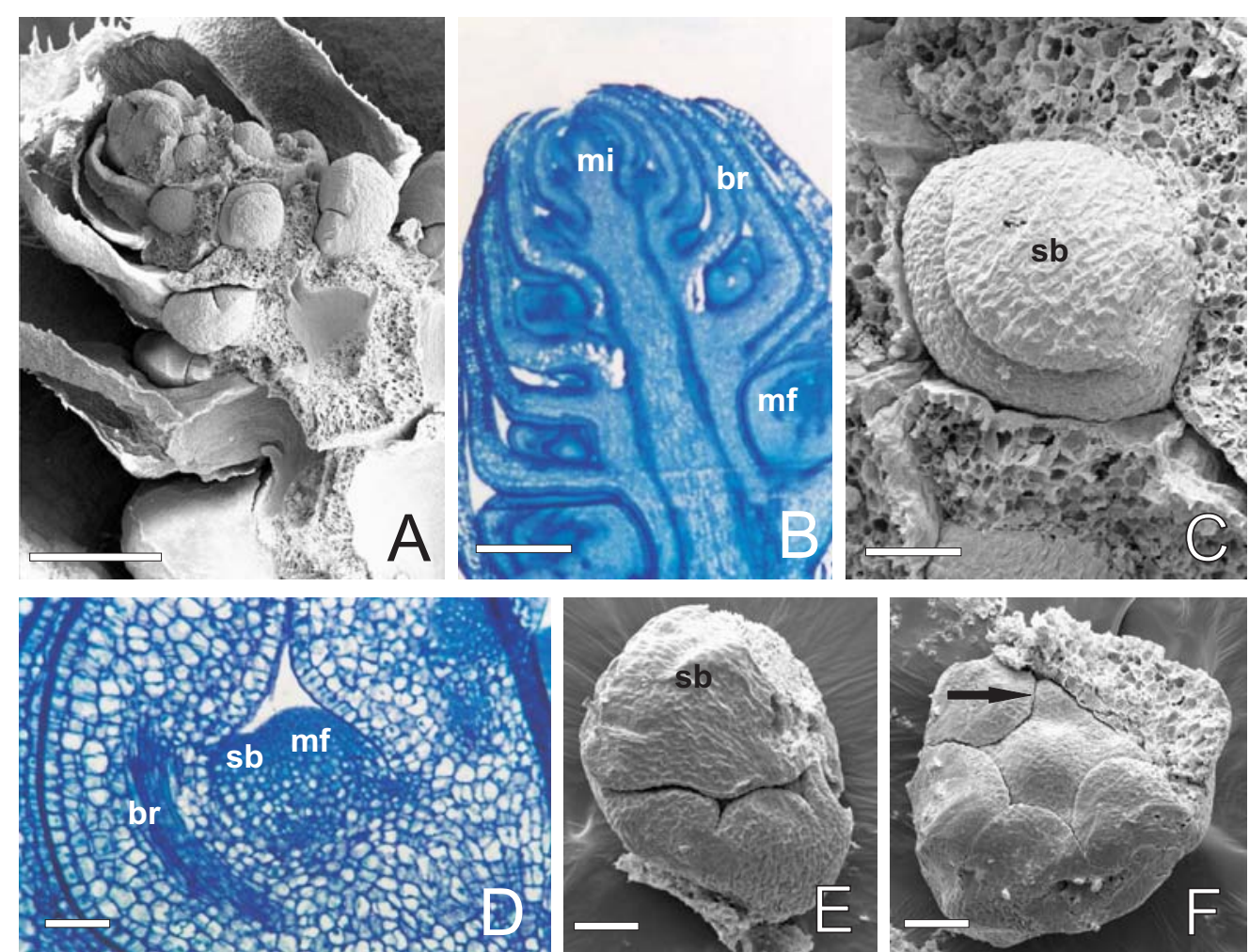

Figura 13 - Imagem de microscopia eletrônica de varredura (A, C, E, F) e de microscopia óptica (B, D) do desenvolvimento floral de Caesalpinia ferrea var leyotachia Benth. A: Inflorescência, mostrando meristemas florais em diferentes estágios de desenvolvimento. B: Corte longitudinal de uma inflorescência mostrando os botões florais, protegidos por brácteas. C, D, E: Meristemas florais no início de diferenciação do primórdio das sépalas. F: Meristema floral onde as setas indicam o início da diferenciação dos primórdios das pétalas (seta). br: bráctea; mf: meristema floral; mi: meristema da inflorescência; sb: primórdio da sépala abaxial. Barras: A: $200 \mu \mathrm{m}$;B, C: $100 \mu \mathrm{m} ; \mathrm{D}, \mathrm{E}, \mathbf{F}: 30 \mu \mathrm{m}$ 
desenvolvimento do carpelo, no centro do meristema floral (figura $13 \mathrm{~F}$ ). Os primórdios dos estames epissépalos e epipétalos permaneceram do mesmo tamanho do primórdio das pétalas, até a formação do primórdio do carpelo (figura 14 A).

O alongamento dos filetes dos estames epissépalos ocorreu quando o primórdio do carpelo iniciou a invaginação do lado adaxial (figura $14 \mathrm{C}$ ). $\mathrm{Na}$ antese as anteras são dorsifixas, com abertura longitudinal para a liberação dos grãos de pólen, apresentando tricomas na base do filete (figuras 15 A, B).

Os grãos de pólen mostraram um tamanho médio de $44,5 \pm 0,5 \mu \mathrm{m}$, com âmbito circular (figura 15 C).

O primórdio do carpelo iniciou-se no centro do meristema floral. Este primórdio alongou-se e quando atingiu a altura de aproximadamente $120 \mu \mathrm{m}$, iniciou-se uma invaginação no lado adaxial, para a diferenciação da placenta (figura 14 B). Esta fenda placentária permaneceu aberta, tornando visível a formação dos primórdios dos óvulos, confirmando a placentação parietal (figuras 14 C, D). As células da região estigmática diferenciaram-se tornandose células papilares alongadas (figura $14 \mathrm{E}$ ). O gineceu próximo à antese se alongou e não foram observados tricomas na sua base, nem o curvamento da região estigmática para o lado adaxial, como observado em sibipiruna e paubrasil (figuras $14 \mathrm{E}, \mathrm{F}$ ). 

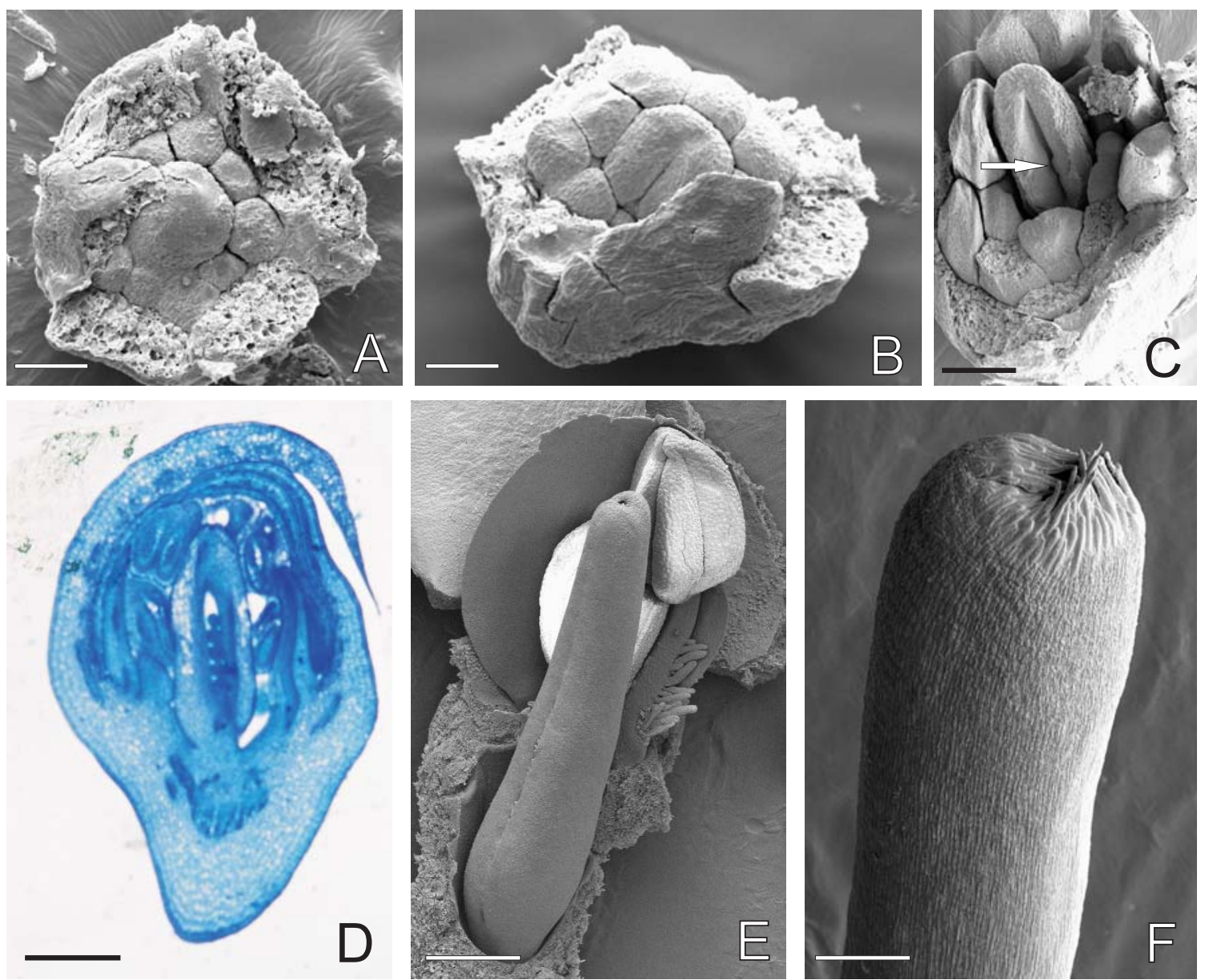

Figura 14 - A: Meristema floral, mostrando o início do desenvolvimento do primórdio do carpelo. B: Meristema floral, em estágio posterior ao mostrado em A. Notar o início da invaginação do lado adaxial do gineceu. C: Gineceu em estágio de formação do primórdio dos óvulos (seta). D: Meristema floral em estágio posterior a C. Notar a placentação parietal do gineceu. E: Gineceu de um botão floral próximo a antese, não há formação de tricomas na base do ovário. F: Gineceu, mostrando as células papilares da região estigmática.Barras: A, B, C: $100 \mu \mathrm{m}$; D, E: $200 \mu \mathrm{m}$; F: $300 \mu \mathrm{m}$ 

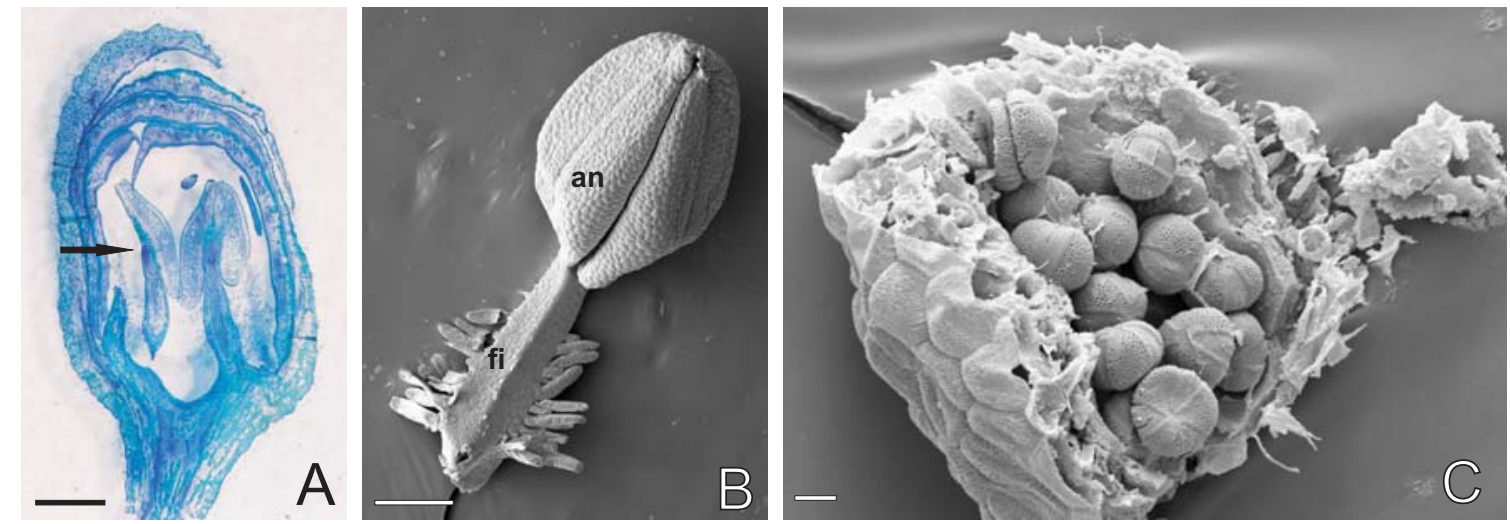

Figura 15 - Imagem de microscopia eletrônica de varredura (B, C) e de microscopia óptica (A) de Caesalpinia ferrea var. leyotachia Benth. A: Corte longitudinal de uma flor, mostrando a ligação dorsifixa do estilete. B: Imagem de um estame, mostrando abertura longitudinal e tricomas na base. C: Grãos de pólen de C. ferrea. an: antera; fi: filete. Barras: A, B: $100 \mu \mathrm{m} ; \mathrm{C}: 30 \mu \mathrm{m}$ 


\section{DISCUSSÃO}

\subsection{Comparação do desenvolvimento floral de C.echinata, C. peltophoroides e C. ferrea var. leyotachia}

Geralmente, o início da floração de pau-brasil, sibipiruna e pau-ferro coincidem com o final da época seca. Em Piracicaba, SP estas condições ocorrem de setembro a março, com pico de floração em outubro. Em pau-ferro a floração ocorre de novembro a fevereiro (Engel, 1984).

O período de floração de pau-brasil é muito curto, nas condições de Piracicaba, SP entre dez a quinze dias, desde a abertura das primeiras flores ao início do desenvolvimento dos frutos. As flores são efêmeras, e após a antese, permanecem abertas por apenas 12-24 horas. As espécies do gênero Caesalpinia possuem características muito similares no tocante à sua ontogenia floral inicial, sendo relativamente uniforme na tribo Caesalpinieae (Tucker, 1984b; 1991; Kantz, 1996). No entanto, o estudo do desenvolvimento floral em diversas espécies de Bauhinia (Tucker, 1984b; 1988) revelou diferenças marcantes na ontogenia floral deste gênero, como a perda de órgãos florais de forma natural, antes da antese. Igualmente, no gênero Cassia 
as diferenças relativas à ontogenia floral são tão importantes entre as espécies que se sugeriu a partição do gênero em três subgêneros (Irwin, 1981).

As três espécies de Caesalpinia aqui estudadas compartilharam muitas características reprodutivas semelhantes como a presença de uma inflorescência indeterminada, flores com simetria bilateral, formação unidirecional das sépalas e pétalas, formação do gineceu por um carpelo único, estigma poroso e tubular, formação de células papilares na região estigmática e a abertura longitudinal das anteras.

C. peltophoroides, C. echinata e C. ferrea apresentam inflorescências do tipo racemo, sendo o tipo mais comum de inflorescência na família Fabaceae, (Tucker, 1996; 2000). As Inflorescências do tipo racemo possuem um meristema apical terminal indeterminado, com iniciação floral acropetalar (Tucker, 2003).

Em C. echinata, C. peltophoroides e C. ferrea as sépalas são iniciadas em ordem unidirecional, como em Microberlinia brazzavillensis e M. bisulcata começando com a formação do primórdio da sépala abaxial (Tucker, 2002a). Em outros gêneros da subfamília Caesalpinioideae, como Amherstia e Tamarindus, a formação dos primórdios das sépalas é seqüencial (Tucker, 2002b; 2003).

A posição imbricada de sépalas e pétalas, observada em $C$ echinata, $C$. peltophoroides e $C$. ferrea, foi descrita em outras espécies das diferentes tribos da subfamília Caesalpinioideae na tribo Caesalpineae: Caesalpinia gilliesii, C. intricata, C. pannosa, Hoffmannseggia drepanocarpa (Kantz \& Tucker, 1994; 
Kantz, 1996); na tribo Cassieae: Cassia javanica, Chamaecrista fasciculata (Tucker, 1992; 1996); na tribo Cercideae: Bauhinia divaricata (Tucker, 1988) e na tribo Detarieae: Saraca indica e S. declinata (Tucker, 2002a).

O desenvolvimento dos estames epipétalos ocorre apenas quando o carpelo já iniciou a formação do sulco longitudinal que originará a placenta nas três espécies estudadas.

O acúmulo de compostos polifenólicos, como observado em C. echinata durante a análise histoquímica não foi observado em C. peltophoroides e C. ferrea.

Em C. peltophoroides e C ferrea var. leyotachia os óvulos começaram a ser iniciados enquanto as margens do carpelo estavam abertas, antes da fusão pós-genital. Os primórdios dos óvulos ficaram expostos até o início da formação dos tegumentos. Não foi possível observar este fato em $C$. echinata. As três espécies apresentaram placentação parietal. Essa condição tem sido descrita para outras espécies de Caesalpinia: Caesalpinia cassioides, C. pulcherrima, C. ovalifolia e C. sepiaria (Kantz \& Tucker, 1994; Kantz, 1996), bem como em outros gêneros da subfamília Caesalpinioideae: Campsiandra, Parkinsonia, Peltophorum e Gymnocladus (Kantz, 1996).

O padrão de desenvolvimento do estigma de $C$. echinata, $C$. peltophoroides e C. ferrea é típico dos gêneros de Caesalpinioideae (Owens, 1989).

Uma das características marcantes da subfamília Caesalpinioideae é a iniciação do carpelo com a formação de uma fenda por invaginação do mesmo 
quando este atinge cerca de $120 \mu \mathrm{m}$. (Tucker, 2002a) Esta característica foi observada em C. echinata, C. peltophoroides e C. ferrea. As três espécies aqui estudadas apresentaram estigma poroso tubular e o curvamento da região estigmática, exceto em C. ferrea, como observado por Tucker (1997), em Delonix sp e Haematoxylum brasiletto (Owens, 1989; Tucker 1997).

Observou-se igualmente um alongamento do estilete proporcionalmente ao tamanho do ovário em C. echinata, C. peltophoroides e C. ferrea à medida que a flor se aproximou da antese. Este alongamento facilitaria a polinização por insetos e não foi observado no gênero Petalostylis (Heel, 1983; Tucker, 1998). 


\section{CONCLUSÕES}

Baseado nos resultados obtidos e nas análises realizadas nesse estudo pode-se concluir que:

- As inflorescências de C. echinata, C. peltophoroides e C. ferrea são do tipo racemo, contendo brácteas protetoras na região abaxial de cada meristema floral;

- Em C. echinata, C. peltophoroides e C. ferrea observou-se o desenvolvimento dos primórdios florais de maneira unidirecional sendo o primórdio abaxial o primeiro a ser diferenciado;

- As anteras são dorsifixas e com abertura do tipo longitudinal, nas três espécies estudadas;

- Próximo à antese, as células da região estigmática diferenciam-se em células papilares alongadas, formando um anel oco, ocorrendo um curvamento deste anel para a região adaxial, exceto em $C$. ferrea;

- As flores na antese são hermafroditas, diclamídeas e pentâmeras, de cor amarela, exceto a pétala adaxial, que possui uma mancha vermelha, nas três espécies estudadas; 
- As espécies do gênero Caesalpinia possuem características similares quanto à sua ontogenia floral, concordando com padrão descrito para a tribo Caesalpinieae.

- C. echinata possui células que acumulam compostos polifenólicos na região abaxial dos primórdios dos órgãos florais;

- C. ferrea não possui tricomas na base do ovário, como observado em C. echinata e C. peltophoroides;

- A descrição morfo-anatômica dos eventos ontogenéticos do desenvolvimento floral das espécies de Caesalpinia documentada nesta dissertação, poderá servir de base para futuros estudos moleculares do desenvolvimento reprodutivo em leguminosas da subfamília Caesalpinioideae. 


\section{REFERÊNCIAS BIBLIOGRÁFICAS}

ALBERCH, P. Problems with the interpretation of development sequences. Systematic Zoology, v.34, p.46-58, 1985.

ALBERCH, P.; GOULD, S. J.; OSTER, G. F.; WAKE, D. B. Size and shape in ontogeny and phylogeny. Paleobiology, v.5, p.296-317, 1979.

ARROYO, M. T. K. Breeding systems and pollination biology in Leguminosae. In POLHILL, R. M.; RAVEN, P. H. (Ed.). Advances in legume systematic. Richmond: Royal Botanic Gardens, Kew. 1981 p. 723-769.

BAUM D. The evolution of plant development. Current Opinion Plant Biology, v.1, p.79-86, 1998.

BRADLEY, D.; RATCLIFFE, O.; VICENT, C.; CARPENTER, R.; COEN, E. Inflorescence commitment and architecture in Arabdopsis thaliana. Science, v.275, p. 80-83, 1997.

BRUNEAU, A.; FOREST, F. Phylogenetic relationships in the Caesalpinioideae (Leguminosae) as inferred from chloroplast trnL sequences. Systematic Botany, v.26, p. 487-514, 2001. 
CARVALHO, P. E. R. Espécies florestais brasileiras. Recomendações silviculturais, potencilaidades e uso da madeira. Colombo: EMBRAPACNPF. 1994, p. 640.

CHAPPILL, J. A. Cladistic analysis of the Leguminosae: The development of an explicit hypothesis. In CRISP, M. D.; DOYLE, J. J. (Ed.). Advances in legumes systematic. Richmond: Royal Botanic Gardens, Kew. 1995. p. 110.

CHASE, M. W.; SOLDIS, D. E.; OLSMSTEADI, R. G., et al. Phylogenetics of seed plants: An analysis of nucleotide sequences from the plastid gene rbcL. Annals of Missouri Botanical Garden, v. 80, p. 528-580, 1993.

COEN, E. S; MEYEROWITZ, E. M. The war of the whorls: Genetics interactions controlling flower development. Nature, v. 353, p.31-37, 1991.

CORRÊA, M. A. Morfologia polínica de Caesalpinia echinata Lam. (Leguminosae - Caesalpinioideae). Revista Brasileira de Botânica, v. 26, p. 35-359, 2003.

COUPLAND, G. Flower development. LEAFY blooms in aspen. Nature, v.377, p. 482-483, 1995.

CRONQUIST, A. An integrated system of classification of flowering plants. New York: Columbia University Press. 1981. p. 1236-1248.

DAHLGREN, R. M. T. General aspects of angiosperm evolution and macrosystematics. Nordical Journal of Botany, v. 3, p.119-149, 1983. 
DOYLE, J. J. DNA data and legume phylogeny: a progress report. Advances in legume systematic. Richmond: Royal Botanic Gardens, Kew. Phylogeny 1995. pt 7. p. 11-30.

DOYLE, J. J.; LUCKOW, M. A. The rest of 5 th iceberg. Legume diversity and evolution in a phylogenetic context. Plant Physiology, v. 131, p. 900-910, 2003.

DOYLE, J. J.; DONOGHUE, M. J.; ZIMMER, E. A. Integration of morphological and ribosomal RNA data on the origin of angiosperms. Annals of Missouri Botanical Garden, v. 81, p. 419-450, 1994.

DOYLE, J. J.; CHAPPILL, J. A.; BAILEY, C. D.; KAJITA, T. Towards a comprehensive phylogeny of legumes: evidences from $r b c L$ sequences and non molecular data. Advances in legume systematic. Richmond: Royal Botanic Gardens, Kew. 2000. pt 9:, p.1-20.

ENDRESS, P. K. Chaotic floral phylotaxis and reduced perianth in Achlys (Berberidaceae). Botanica Acta, v. 102, p. 159-164, 1989.

ENGEL, V. L.; MORAIS, A. L.; POGGIANI, F. Guia de localização e reconhecimento das principais espécies arbóreas do Parque da Esalq. 1984 FEALQ.

GOULD, S. J. Ontogeny and phylogeny. Cambridge: Belknap Press of Harvard University Press, 1977.

HEEL, W. A. The ascidiform early development of free carpels. A SEM Investigation Blumea, v. 28, p.231-270, 1983. 
HUFFORD, L; DIGGLE, P. K. The morphology and evolution of flowers: a tribute to the work of Shirley Tucker: an introduction. International Journal Plant Science, v.158, (Supplement) n.6, p. S1-S2, 1997.

IRWIN, H. S.; BARNeBY, R. C. Cassieae. In POLHILL, R. M; RAVEN, P. H. (Ed.). Advances in legume systematic. Richmond: Royal Botanic Gardens, Kew. 1981. pt. 1, p. 97-106.

JUDD, W. S.; CAMPBELL C. S.; KELLOGG E. A.; et al. Plant systematic phylogenetic approach. Sinauer Associates, 1999. p 283-288.

KAJITA, T.; OHASHI, H.; TATEISHI, Y.; DOYLE, J. J. rbcL and legume phylogeny, with particular reference to Phaseoleae, Millettieae, and allies. Systematic Botany, v.26, p. 515-536, 2001.

KANTZ, K. E.; TUCKER, S. C. Developmental basis of floral characters in the Caesalpineae. In: FERGUSON, I. K; TUCKER, S. C. (Ed.). Advances in legume systematic. Richmond: Royal Botanic Gardens, Kew. 1994. p. 63340: Structural Botany.

KANTZ, K. E. Floral development in the Caesalpinioid tribe Caesalpinieae (Fabaceae). Baton Rouge, 1996. Thesis (Ph. D.)-Louisiana State University.

KOORNNEEF, M; HANHART, C. J.; VEEN van der J. H. A genetic and physiological analysis of late flowering mutants in Arabidopsis thaliana. Molecular General Genetics, v. 229, p.57-66, 1991.

LAVIN, M. A cladistic analysis of the tribe Robinieae (Papilionoideae, Leguminosae. Advances in legume systematic. In STIRTON, C. H. (Ed.). Richmond: Royal Botanic Gardens, Kew. 1987, pt. 3, p. 31-64. 
LEWIS, G. P. Caesalpinia, a revision of the Poncianella - Erysthrostemon group. Richmond: Royal Botanic Gardens, Kew, 1998.p. 210-217.

LIMA, H. C. Aspectos botânicos do pau-brasil. Viagem à terra do pau-brasil. In: CUNHA, M. V.; LIMA H. C (Ed.). Rio de Janeiro: Agência Brasileira de Cultura. 1992. p. 23-38.

LORENZI, H. Árvores brasileiras - Manual de identificação e cultivo de plantas arbóreas nativas do Brasil. Nova Odessa: Editora Plantarum, 2000. v.1, p.290.

LORENZI, H. Árvores brasileiras - Manual de identificação e cultivo de plantas arbóreas nativas do Brasil. Nova Odessa: Editora Plantarum. 2002. v.2, p.352.

MCKEY, D. Interactions between ants and leguminous plants. Monographs in Systematic Botany. Missouri Botanical Garden, v. 29, p. 673-718, 1989.

O'BRIEN, T. P.; FEDER, N.; CULLY, M. E. Polychromatic staining of plant cell walls by toluidine blue Protoplasm, v. 59, p. 368-373, 1964.

OWENS, S. Stigma, style, pollen, and the pollen-stigma interaction in Caesalpinioideae. In: STIRTON, C. H.; ZARUCCHI J. L. (Ed.). Advance in legume biology.: Richmond: Missouri Botanical Garden, Kew. 1989, v.2, p. 113-126. (Monographs in Sistematic Botany.)

POLHILL, R. M.; RAVEN, P. H. Advances in legume systematic. Richmond: Royal Botanic Garden, Kew, 1981, pt 1. 
POLHILL, R. M.; RAVEN, P. H.; STIRTON, C. H. (Ed.). Evolution and systematics of the Leguminosae. Advances in legume systematics. Richmond: Royal Botanic Gardens, Kew. 1981. pt 1, p. 1-26.

RODRIGUEZ, A. P. M.; WETZSTEIN, H. Y. A morphological and histological comparison of the initiation and development of pecan (Carya illinoinensis) somatic embryogenic cultures induced with naphtaleneacetic acid or 2,4dichlorophenoxyyacetic acids. Protoplasma, v.204, p.71-83, 1998.

THEISSEN, G.; BECKER, A.; DI ROSA, et al. A short history of MADS-box genes in plants. Plant Molecular Biology, v. 42, p.115-149, 2000.

TRUMP, B. F.; SMUCKLER, E. A.; BENEDITT E. P. A method for staining epoxy sections for light microscopy. Journal Ultrastructure Research, v. 5, p. 343-348, 1961.

TUCKER, S. C. Origin and symmetry in flowers. In: WHITE, R. A.; DICKISON, W. C., (Ed.). Contemporany problems in plant anatomy. New York: Academic Press, 1984a.p. 354-395.

TUCKER, S. C. Unidirectional organ initiation in leguminous flowers. American Journal of Botany, v. 71, p. 1139-1148, 1984b.

TUCKER, S. C. Floral initiation and development in legumes. In: STIRTON, C. H. (Ed.). Advances in legume systematic. Richmond: Royal Botanic Gardens, Kew. 1987. pt 3, p. 183-239.

TUCKER, S. C. Dioecy in Bauhinia resulting from organ suppression. American Journal of Botany, v. 75, p. 1584-1597, 1988. 
TUCKER, S. C. Helical floral organogenesis in Gleditsia, a primitive caesalpinioid legume. American Journal of Botany, v. 78, p.1130-1149, 1991.

TUCKER, S. C. The developmental basis for sexual expression in Ceratonia siliqua (Leguminosae: Caesalpinioideae: Cassieae). American Journal of Botany, v. 79, p. 318-327, 1992.

TUCKER, S. C. Trends in evolution of floral ontogeny in Cassia sensu stricto, Senna, and Chamaecrista (Leguminosae: Caesalpinioideae: Cassieae: Cassiinae); a study in convergence. American Journal of Botany, v. 83, p. 687-711, 1996.

TUCKER, S. C. Floral ontogeny in Legume genera Petalostylis, Labichea, and Dialium (Caesalpinioideae: Cassieae), a series in floral reduction. American Journal of Botany, v. 85, n.2, p. 184-208, 1998.

TUCKER, S. C. Evolutionary liability of symmetry in early floral development. International Journal of Plant Science, v. 160, n. 6, p. S25-S39, 1999.

TUCKER, S. C. Floral development in tribe Detarieae (Leguminosae: Caesalpinioideae): Amherstia, Brownea, and Tamarindus. American Journal of Botany, v. 87, n.10, p.1385-1407, 2000.

TUCKER, S. C. Comparative floral ontogeny in Detarieae (Leguminosae: Caesalpinioideae) 1. Radially symmetrical taxa lacking organ suppression. American Journal of Botany, v. 89, n.6, p. 888-907, 2002. 
TUCKER, S. C. Comparative floral ontogeny in Detarieae (Leguminosae: Caesalpinioideae). 2. Zygomorphic taxa with petal and stamen suppression. American Journal of Botany, v.89, n.6, p. 888-907, 2002.

TUCKER, S. C; DOUGLAS, A. W. Ontogenic evidence and phylogenetic relationship among basal taxa of legumes. In: FERGUSON, K.; TUCKER, S. (Ed.). Advances in legume systematic. Richmond: Royal Botanic Gardens, Kew 1994. pt 6, p.11-32.

TUCKER, S. C.; KANTZ, K. E. Comparative floral development and evolution in tribe Caesalpinieae (Leguminosae: Caesalpinoideae). Haematoxylum. American Journal of Botany, v. 84, n.9, p. 1047-1063, 1997.

TUCKER, S. C.; STEIN, O. L.; DERSTINE, K. S. Floral development in Caesalpinia (Leguminosae). American Journal of Botany, v. 72, p. 14241434, 1985.

TUCKER, S. C. Floral development in legumes. Plant Physiology, v. 131, p. 911-926, 2003.

VAUGHAN, J. G. The morphology and growth of the vegetative and reproductive apices of Arabidopsis thaliana (L) Hyeyh., Capsella bursapastoris (L) Medic. and Anagallis arvenis, Journal London Botany Society, v. 55, p. 279-301, 1955.

WEIGEL, D; ALVAREZ, J; SMYTH, D. R; YANOFSKY M. F; MEYEROWITZ, E. M. LEAFY controls floral meristem identify in Arabdopsis thaliana. Cell v. 69, p.843-859, 1992. 
WOJCIECHOWSKI, M. F. Reconstructing the phylogeny of legumes (Leguminosae): an early $21^{\text {st }}$ century perspective. Advances in legume systematics. Richmond: Royal Botanic Gardens, Kew. 2003. pt. 10.

YANOVSKY, M. F.; DEVLIN, P. F.; KAY, S. A. A genomic analysis of the shade avoidance response in Arabidopsis. Plant Phisiology, v. 4, p. 1617-1629, 2003. 